\title{
NUEVOS MUSEOS PARA LA ENSEÑANZA DEL PATRIMONIO CULTURAL. EL "MUSEO VIVO" DE HISTORIA DEL ARTE
}

María Villalba Salvador ${ }^{1}$ Universidad Autónoma de Madrid

Recibido 02/12/2019 Aceptado 16/12/2019

\begin{abstract}
Este texto, a partir de la revisión de nuevas prácticas existentes en los museos en la actualidad, presenta un proyecto educativo innovador que parte del Departamento de Didácticas Específicas de la Universidad Autónoma de Madrid: "Museo Vivo de Historia del Arte", que pretende ser, en el ámbito universitario, una herramienta útil para la enseñanza y aprendizaje de esta disciplina y de la Ciencias Sociales. Se basa en la creación de una colección de objetos contemporáneos y cotidianos indicativos de que el patrimonio está al alcance de nuestra mano. En este caso, en torno a la moneda y su capacidad de generar puntos de encuentro entre las matemáticas, el arte y las ciencias
\end{abstract} sociales.

Upon reviewing currently new practices in museums, this paper presents an innovative educational project that comes from the Specific Didactics Department from Universidad Autónoma de Madrid: Living Museum of Art History, which claims to be a useful tool for teaching and learning this subject and social sciences in the academic field. It is based on the creation of an everyday objects collection, which indicates that the heritage is at our fingertips. In this case, around the coin and its capacity to create meeting points among mathematics, art and social sciences.

DOI

https://doi.org/10.15366/didacticas2019.21.004

\section{Palabras clave}

Museo Vivo; Didáctica de la Historia del Arte; Moneda; Patrimonio cultural; Museos y educación.

Living museum; Didactics on Art History; Coin; Cultural heritage; Museums and education. 


\section{INTRODUCCIÓN7}

Desde la transición del siglo XX al siglo XXI se viene hablando en materia de museología de un cambio en las relaciones entre la sociedad y la institución museística, de tal manera que se están gestando nuevas prácticas y materializaciones en este ámbito que posibilitan la instauración de nuevos museos, hasta entonces difíciles de imaginar y que, sin embargo, muestran a este tipo de instituciones como algo extremadamente vital y beneficioso para la sociedad. Por su parte, ésta se compromete con el museo a la conservación y salvaguarda de nuestro patrimonio histórico artístico (León, 2010: 339-40).

El mismo concepto de museo se ha visto revisado, lo hace periódicamente el ICOM y quizás esté motivado, entre otras cosas, por los cuestionamientos que se producen respecto a la propia institución (Cerrolaza, 2018: 81) y por los cambios sustanciales que se vienen produciendo en las tipologías de museos, que han llegado a cuestionar su carácter patrimonial. Hasta tal punto, que se ha llegado a decir que "en la actualidad nos encontramos con un amplio abanico de museos que ha llevado a trivializar el mismo concepto de museo porque, bajo ese término, entra todo" (Hernández, 2002: 74). Por ello conviene recordar, aunque sea algo muy conocido, la definición de museo como "una institución sin fines lucrativos, permanente, al servicio de la sociedad y de su desarrollo, abierta al público, que adquiere, conserva, investiga, comunica y expone el patrimonio material e inmaterial de la humanidad y su medio ambiente con fines de educación, estudio y recreo", en "El reto de revisar la definición de museo" (ICOM, 2017). Definición que aparece recogida, de manera muy similar, en nuestra Ley de Patrimonio 16/1985 y el Reglamento de Titularidad Estatal y del Sistema Español de Museos (BOE 13/05/1987), que se basa en la definición consignada en los Estatutos del ICOM de 1974, con mínimas modificaciones. El significado del término se ha ido ampliando caracterizándolos como lugares para la evocación y la interpretación, o como instrumentos que nos informan y facilitan la comprensión del ser humano, de sí mismo y de su relación con la sociedad, el arte y la naturaleza (Desvallées y Mairesse, (2010): 52-54), ofreciendo visiones sobre los museos que nos acercan también a las nuevas modalidades de esta institución.

Así, al hilo de la definición, podemos encontrar museos de carácter material o inmaterial en el borne entre lo que ha sido la institución tradicionalmente considerada y lo que serán los museos del futuro. Digamos que el gran cambio se está produciendo en el siglo XXI, pero no podemos olvidar que los primeros pasos se dieron en el siglo XX: el Atlas

\footnotetext{
1 El proyecto fue presentado en las 19 Jornadas DEAC (2016) por cuatro investigadoras vinculadas la Universidad Autónoma de Madrid y la Universidad de Granada: Guadalupe Romero, Carmen Blanco, Encarnación Cambil y yo misma. Con posterioridad lo presenté en el Seminario Las Matemáticas y el Museo Pedagógico Jesús Asensi. Puntos de encuentro con las Ciencias Experimentales y las Ciencias Sociales, dirigido por el Profesor Javier Peralta, con la ponencia: "Arte y matemáticas en el Museo Pedagógico Jesús Asensi. Presentación de la primera caja del Proyecto Museo Vivo del Departamento" (17/11/2016), y en el Seminario "Historia del Arte y Educación en el contexto de la UNES", organizado por el Departamento de Ciencias Sociales de la Universidad de Granada, codirigido por las profesoras Encarnación Cambil y Guadalupe Romero, con la ponencia Museo Vivo de didáctica de la Historia del Arte en el MPJA de la UAM. Presentación de la primera caja "Arte, monedas y matemáticas. Punto de encuentro" (2/12/2016). A todos quiero agradecer el apoyo prestado, especialmente a la profesora Carmen Blanco, impulsora del proyecto MUSEO VIVO.
} 
Mnemosyne, en el que Abby Warburg trabajó entre 1924 y 1929, un proyecto interdisciplinar centrado en el universo artístico de la Edad Moderna, que incluye mapas, emblemas, motivos alegóricos, porciones de obras artísticas, fragmentos de la vida cotidiana, sueltos de prensa o reglas matemáticas, configurado todo ello en 60 paneles fotografiados de un atlas que no se terminó y que constituye la obra póstuma de su autor, además de un precedente claro del museo virtual (Reguera, 2010). Otros ejemplos son La boite-en-valise, de Marcel Duchamp, de la que más adelante hablaremos, puesto que su formato es de caja, y El museo imaginario, de Malraux cuya primera edición publicada en 1947 presentaba como idea un museo de imágenes, ilimitado, sin muros, portátil y manejable por su dueño, auténtico artífice personal del mismo (Malraux, 2017). Silvia Cerrolaza cita otros museos portátiles, como el Museo de los Cajones, de Herbert Distel (1970-77), el John Erickson Museum (2003) o El Davis Museum de Davis Lisboa (2009) encerrado en una urna (p. 84), de tal manera que "el museo se vuelve móvil y sin límites, disuelve sus fronteras para intervenir en el mundo. El edificio museístico no es imprescindible para la existencia del museo. La institución se está adaptando lentamente a una sociedad cada vez más regida por la movilidad, tanto física como mental, y por la inmaterialidad y, en consecuencia, el museo se está convirtiendo en una realidad más inmaterial. Se podría decir que está mutando hacía una institución variable e incluso efímera (...) que no requiere de grandes infraestructuras ni de asombrosos edificios para realizar sus funciones” (Cerrolaza, p. 88). El hecho es que la realidad nos ofrece nuevos museos en espacios sorprendentes.

El proyecto de museo que aquí se presenta tiene que ver, además de con las tendencias de la nueva museología, con la llamada museografía didáctica y con la enseñanza del patrimonio cultural. Por medio de ésta se trata de poner al alumno en contacto con los bienes culturales y fomentar su aprendizaje como bien heredado del pasado, como legado colectivo y seña de identidad, y como algo que es siempre contemporáneo y que se constituye como un importante elemento educativo. Cuando hablamos de patrimonio nos referimos a certezas que nos permiten una aproximación científica y un trabajo de análisis que requiere un método de trabajo y una práctica propias de los contextos de aprendizaje (Fontal, 2008: 79-109). El Plan Nacional de Educación y Patrimonio puesto en marcha en el año 2013, basándose en la normativa vigente, recoge la ampliación del concepto de Patrimonio histórico artístico al de Patrimonio Cultural y lo articula como "un único hecho sociocultural, constituido de manera holística por manifestaciones de carácter diverso -histórico, artístico, etnológico, científico-tecnológico y natural-, que en conjunción permiten el conocimiento de las diferentes sociedades tanto del pasado como del presente" (Carrión Gutiez, 2015: 11). Podemos entenderlo también como un espacio interdisciplinar, integrador de conocimientos que se manifiestan en una única realidad significativa respecto a las ciencias sociales, incluso a otras como las ciencias o las matemáticas, pues como señalan Santacana y Serrat, "el campo del patrimonio se ha convertido en un espacio imaginativo por definición. Prácticamente cualquier elemento puede convertirse en un sólido referente patrimonial y despertar expectativas, sobre todo si se muestra con una museografía sugerente que plantee interrogantes y sepa transmitir conocimientos a partir de planteamientos 
comprensivos. (...) No hay límites a la imaginación” (Santacana y Serrat, 2011: 26-27). Se trata de un ámbito para el que las didácticas de área o específicas (González Gallego, 2002: 11-34) han experimentado un crecimiento y una relevancia considerable, en concreto la didáctica de las ciencias sociales, susceptibles de utilización en el campo de la museología y el patrimonio, para cualquier tipo de público o receptor.

En este sentido conviene recordar que tanto la museología como la museografía son necesarias dada la condición de custodia y salvaguarda propia del museo, así como el hecho sociocultural que le es propio. La museología es la ciencia del museo, la museografía es "la actividad, disciplina o ciencia (según se considere) que tiene como objeto principal las exposiciones, su diseño y ejecución así como la adecuación y museización de determinados espacios para facilitar su presentación y su comprensión” (Hernández Cardona, 2011: 49-50). La realidad es que la museología necesita de otras ciencias dado su carácter interdisciplinar, como la museografía, de naturaleza pasajera pero siempre necesaria, y de las didácticas específicas, para dar vida a una institución de carácter permanente pero en constante movimiento (Alonso Fernandez, 1999: 33-34). Estas últimas tienen como objetivo hacer educativo su conocimiento propio, de tal manera que hoy en día son muy necesarias las museografías didácticas, en detrimento de los aspectos estrictamente formales y en beneficio de la comprensión de los objetos inmersos en el discurso expositivo. En este sentido, cuando nos ceñimos al entorno educativo, es evidente que el docente puede convertirse en museógrafo ya que, en un espacio interdisciplinar, las posibilidades que ofrece un objeto expuesto en el museo_exigen el conocimiento científico por parte del profesorado. La coincidencia de intereses entre museografía y didácticas específicas está en la atracción y lo sugestivo de la comunicación y de la comprensión de los objetos.

Como señala Neil MacGregor (2012), contar las cosas a través de los objetos es lo que hacen los museos, a los que califica como señales del pasado (pp. 17 y 19), siguiendo el camino abierto en la museología por Georges Henry Rivière (1989). En España, los trabajos de García Blanco (1994), Santacana i Mestre y Serrat Antolí (2011) y Santacana i Mestre y Llonch Molina (2012), inciden en esta vía de trabajo. Al formar el discurso museológico, la exposición se convierte en un medio de comunicación que busca el diálogo entre emisor y receptor. Como en todo mensaje comunicativo se ponen en juego una serie de conceptos, en este caso a través de los objetos que ejercen un efecto de llamada y generan una red de nociones y pensamientos que el espectador va encadenando. En el caso de que el proyecto esté destinado a la docencia y de que el alumno pueda convertirse en destinatario específico, este puede incluso involucrarse de distintos modos y aportar sus ideas, incluso nuevos objetos relacionados con los expuestos, de modo que se produzca una total interacción que beneficie a la adquisición de conocimientos (Santacana Mestre, 2011: 81-87).

Llegados a este punto, la pregunta es cómo desarrollar un buen proyecto educativo para un museo, que es de lo que trata este artículo en su pretensión de poner en juego distintas disciplinas vinculadas a lo que vamos a llamar museo vivo ligado al Museo Pedagógico 
Jesús Asensi de la Universidad Autónoma de Madrid². En primer lugar, entonces, es necesario recordar que las recientes investigaciones y líneas de trabajo sobre los museos pedagógicos los caracterizan como "espacios que se mueven entre la memoria y la creatividad, (...) espacios aptos para exponer y difundir el patrimonio educativo a través de planteamientos, propuestas, actividades y talleres didácticos desarrollados por ellos mismos" (Álvarez Domínguez, 2016:19-20). Estas instituciones custodian la memoria de la escuela española y son esenciales para conocer la trayectoria de la educación en España, tanto desde el conocimiento de lo tangible como de lo intangible. Revitalizar sus fondos, sus colecciones y ponerlas a disposición de los estudiantes llamados a ser los maestros del futuro, puede ser uno de los grandes objetivos en los que centrar su utilidad. Del mismo modo, ponerlas a disposición de los estudiantes de educación infantil, primaria y secundaria es ayudarles a conocer nuestro pasado para entender mejor el presente, mediante el acercamiento al patrimonio educativo (Álvarez Domínguez, 2016: 28-29). Estos museos son idóneos para crear proyectos interdisciplinares de carácter pedagógico que tengan como objetivo analizar el patrimonio educativo, ejemplo nítido de confluencia de distintas disciplinas que multiplican las posibilidades educativas y que nos ayudan a pensar sobre la realidad objetiva. Para Julio Ruiz Berrio (2006), el proceso de crecimiento que han experimentado estas instituciones es acorde con los principios de la Nueva Museología, no tan centralizada en su estructura y más atenta a lo interdisciplinar, lo que les convierte en lugares de encuentro y centros de recuperación del patrimonio educativo y cultural al servicio de los distintos públicos, de todos los públicos, con el ánimo de enseñar (p. 271-275). La historiografía reciente ha dedicado gran atención a estos museos (Viñao. 2012; Álvarez Domínguez y Payá Rico, 2015; Ruiz Berrio, 2010; Rivera, R., García Fernández, 2015), contribuyendo a su visión como centros que coadyuvan a concienciar a la población sobre su identidad y a recuperar el conocimiento del pasado a través de los objetos (Carreño, M. 2007).

Como señalan Cuenca López y Martín Cáceres (2014), en todo proyecto educativo de museos, el punto de partida debe estar claro en cuanto al punto de llegada: la interpretación por parte del público y sus contenidos deben incidir en la mejora del conocimiento de los bienes culturales, y propiciar su puesta en funcionamiento en la enseñanza formal o reglada. Para ello, debe haber una rigurosa selección de contenidos, que pueden agruparse según distintos criterios que faciliten los procedimientos adecuados para extraer toda la información posible de los objetos seleccionados mediante la observación, el análisis y la interpretación, entre otros, por lo que es evidente que son imprescindibles las didácticas específicas para el proceso de enseñanza y aprendizaje (p. 16-22). En este sentido son fundamentales las didácticas de las Ciencias Sociales, en especial las de la Historia y la Historia del Arte y el Patrimonio Cultural. Como señala Susan Pearce (1994) los objetos, designados en su conjunto como cultura material, encierran valores humanos, lo mismo que lo que los anglosajones denominan "artefacto", que lleva implícita la factura de carácter artístico. De tal manera que el pasado sobrevive en los objetos de tres modos: entendidos

2 Museo Pedagógico Jesús Asensi (UAM), [Enlace]. Última consulta: 2/08/2019 
como resultado del espíritu humano; como paisaje material, y como relato que enlaza con recuerdos personales, vinculados incluso a alguno de los cinco sentidos, pues cuentan su historia, como cualquier narrativa de carácter verbal o pictórica, de modo significativo (928). La didáctica de la Historia del Arte y del Patrimonio Histórico Artístico pasa hoy en día por hacer un cambio de planteamiento sin olvidar los contenidos, cruciales en cualquier disciplina. Sobre este tema y su tratamiento en los distintos currículos de leyes sucesivas podemos citar algunos trabajos tanto de nuestras leyes como las de otros países (Reyes Leoz y Méndez Andrés, 2016; Fontal Merillas, Ibáñez-Etxeberria, Martínez Rodríguez, y Rivero Gracia, 2017; González Monfort, 2011), cuyas revisiones acerca de la presencia de la didáctica del patrimonio en la normativa estatal, desde la Ley Orgánica General del Sistema Educativo (LOGSE) a la Ley Orgánica de la Mejora Educativa (LOMCE), dan buena cuenta de la evolución que ha sufrido el concepto de patrimonio cultural en las distintas leyes educativas, desde algo que impregnaba de distintas maneras las diferentes materias, hasta la actualidad, donde el aprendizaje y enseñanza del mismo ha perdido fuerza debido a la presencia de los estándares de aprendizaje que contemplan quizás más los contenidos que los procesos de aprendizaje.

Por otra parte, la importancia de una didáctica específica de la Historia del Arte venía ya señalada con fuerza por Bartolomé Cossío y el pensamiento de los integrantes de la Institución Libre de Enseñanza (ILE), que basaban sus principios en planteamientos de experimentación y, en ese sentido, en la necesidad de tener en cuenta los museos como referentes y objetos de trabajo, sobre los cuales Manuel B. Cossío proyectaba el arte de saber ver el mundo entero para que el niño aprendiera a contemplar y a pensar todo lo que le rodeaba, con el afán de educar antes que instruir (Villalba Salvador, 2019).

El importante papel de la Institución Libre de Enseñanza y de los institucionistas ha sido estudiado por Natividad Ortega Morales (2002), que reivindica, siguiendo las innovaciones de la ILE, la importancia de la educación estética en una formación integral, sin olvidar, por otra parte, el papel cada vez más importante del arte en la sociedad de nuestro tiempo. Desde finales del siglo XX, distintas voces hacían notar la disminución de atención a la historia del arte en los programas curriculares (Socías, I., 1996), así como la preeminencia de un aprendizaje de tipo formal que menoscababa otros aspectos de carácter artístico, cultural y sociológico, tan necesarios para una formación rigurosa respecto a las creaciones artísticas. Llamaba la atención sobre el hecho de que las Ciencias Sociales se beneficiarían de las aportaciones procedentes de los bienes culturales y patrimoniales (pp. 7-16). Rosa María Ávila planteaba en el año 2001 el estado actual de la disciplina de Historia del Arte en el curriculum y profundizaba en una propuesta didáctica para la enseñanza obligatoria de carácter más social. Más adelante detectaba las dificultades de la enseñanza del Patrimonio Histórico Artístico (2003) El museo surgía así como una alternativa posible para la enseñanza y la puesta en práctica de una educación visual, cultural y estética, siguiendo los pasos de lo que venía sucediendo en Estados Unidos, propiciando en los alumnos interpretaciones y respuestas de índole personal y social ante las obras de 
arte (Woodlin, 1997). En esta línea, Olaia Fontal (2009) hace una revisión del museo como institución viva y susceptible de sufragar las carencias de que adolece la educación artística. Para ello detecta una serie de museos que están modificando sus programas educativos y sus discursos museológicos, ante la consciencia de que el arte nos facilita acercarnos a conocimientos que van más allá de los contenidos y que propician sensaciones, vinculan la obra a nuestra memoria, a actitudes y a valores que vienen dados por el conjunto de experiencias que confluyen en el museo (pp. 79-81). La idea de la necesidad de que la escuela y el museo unan esfuerzos se repite en distintos estudios (Serrano Moral, 2018; Calaf y Fontal, 2010; Fontal Merillas, Marín Cepeda, García Ceballos, 2015, y aunque es tradición la visita a estas instituciones por parte de los centros, lo que debe cambiar es el planteamiento de las mismas (Serrano Moral, 811) en un sentido integrador e interdisciplinar, tanto en la formación de maestros, como en las repercusiones de su enseñanza en el alumnado (Bajo, Bajo, 2018). La didáctica de la Historia el Arte y el Patrimonio Cultural junto con el patrimonio educativo, es relevante en cuanto que es una herramienta reconocida a nivel internacional y su trayectoria investigativa en España es reconocida (Vázquez Ramil, 2018). La necesidad de incluir un método didáctico adecuado a las necesidades de cada etapa de aprendizaje se ve ayudado por la llamada enseñanza de los objetos, que puede facilitar un aprendizaje sólido y significativo a la enseñanza de las Ciencias Sociales y, en concreto de la Historia del Arte y el Patrimonio Cultural, pues como señala Herrero Fabregat (2012) "el objetivo fundamental de las ciencias sociales es que el alumno se sitúe ante la sociedad en que vive y la comprenda críticamente" (p. 142). Por ello el proyecto que aquí presentamos se sitúa en un lugar de encuentro entre distintas disciplinas, mediante la observación y la indagación a través de una serie de objetos que vinculan conceptos de carácter artístico, histórico, matemático, económico, turístico y geográfico. Las repercusiones en el alumnado, que nos ayuden a constatar el potencial que posee la didáctica del objeto en este contexto (Egea Vivanco y Arias Ferrer, 2018), es algo que está todavía por hacer.

\section{EL MARCO (DEL MUSEO VIVO)}

Teniendo en cuenta todo lo anterior, este trabajo aborda el estudio y la explicación del proyecto Museo Vivo que pretende ser un instrumento útil para la didáctica de la Historia del Arte. Fue presentado sucintamente en las 19 Jornadas DEAC (Departamentos de Educación y Acción Cultural de Museos) Conjugar Participar (DEAC, 2016). Se anunciaba entonces con el título "Un "museo vivo" para conocer, disfrutar y aprender", y su principal propósito era la creación de un espacio físico y virtual en el que concentrar y reunir aquellos objetos que, independientemente de para qué fueran creados, fuesen herramientas útiles para la enseñanza y aprendizaje de las disciplinas sociales, aunque con el paso del tiempo también pudiera atender a otras áreas e intereses, en búsqueda de una transversalidad necesaria en la educación de hoy en día. 
Ya entonces se hablaba de la necesidad de revitalizar los Museos Pedagógicos existentes en museos contemporáneos para generar un diálogo entre la memoria del pasado y la actualidad educativa del presente (Álvarez Domínguez, 2016, Asensi Díaz, 2015; García Andújar, 2015; Romero Sánchez, 2017).

Para contribuir a ello, el planteamiento se basaba en presentar (previo estudio) una selección de materiales cuyo nexo era haber sido editados en esta centuria y haber sido adquiridos en las principales instituciones culturales públicas o privadas de Madrid y de Andalucía, así como objetos de uso cotidiano indicativos de que nuestro patrimonio está al alcance de nuestra mano. Nos proponíamos que el museo tuviera una doble sede física en ambas universidades (Madrid y Granada), pero también una sede virtual en la que se aglutinarían todas las piezas en estudio. Todo iría encontrando su hueco.

El punto de partida se sitúa en el Departamento de Didácticas Específicas y el Museo Pedagógico Jesús Asensi (MPJA, en adelante)) de la Universidad Autónoma de Madrid (UAM), y la puesta en valor de la memoria del pasado y de algunos de los objetos que posee en su colección. Ésta se debe a la iniciativa del Profesor Jesús Asensi, que lo fue del Departamento de Didáctica y Teoría de la Educación de la UAM, y reúne unos fondos representativos de lo que ha sido la educación primaria y secundaria en nuestro país desde hace siglo y medio, con un repertorio muy importante de libros escolares (Asensi Díaz, 2015; Romero Sánchez, 2017).

El punto de llegada es el de la creación de una sección contemporánea por medio de diferentes cajas pensadas para la didáctica de historia del arte, que puedan incluirse en los programas docentes y ser aprovechadas por nuestros actuales estudiantes.

Los objetivos del proyecto se planteaban, y se plantean, de la siguiente manera: en primer lugar aunar objetos que favorezcan la enseñanza-aprendizaje de las disciplinas sociales para, progresivamente, crear una sección específica para la Didáctica de la Historia del Arte, realizar un análisis crítico de dichos objetos y poner de relieve las carencias detectadas durante el estudio aportando ideas que contribuyan a solventarlas.

El método de trabajo deviene de relacionar las nuevas cajas del museo con los programas docentes de los departamentos universitarios de las Facultades de Educación y su vinculación a los Grados de Maestro en Educación Infantil y Maestro en Educación Primaria. En síntesis, se apuesta por una didáctica que, sin perder su identidad, señale en las especialidades de educación infantil (3-6 años) y educación primaria (6-12 años) los puntos de encuentro con otras disciplinas.

\section{EXPLICACIÓN DEL PROYECTO}

Tras un intenso trabajo de campo constatamos la necesidad de reunir objetos didácticos que considerábamos relevantes para utilizarlos, tanto de forma individual como en conjunto. Se trata de un espacio vivo y por tanto en constante crecimiento en el que poder 
interactuar, así como plantear y replantear estrategias y temáticas en función de los objetivos que se quieran conseguir.

Al hablar de museo vivo no podemos dejar de hacer referencia al artista Alberto Greco (1931-1965) y su Manifiesto Dito del Arte Vivo (Greco, 1962), que reza como sigue a continuación:

"El arte vivo es la aventura de lo real. El artista enseñará a ver no con el cuadro sino con el dedo. Enseñará a ver nuevamente aquello que sucede en la calle. El arte vivo busca el objeto pero al objeto encontrado lo deja en su lugar, no lo transforma, no lo mejora, no lo lleva a la galería de arte. El arte vivo es contemplación y comunicación directa. Quiere terminar con la premeditación que significa galería y muestra. Debemos meternos en contacto con los elementos vivos de nuestra realidad (...) Arte Vivo, Movimiento Dito. Alberto Greco. 24 de julio de 1962. Hora: 11:30".

También desde la museología, como señala Poulot (2011:109), "hoy, tendencialmente, el museo no deja nada fuera de su alcance, ni de las cosas, ni de los usos. Con la antropología y la etnología, los objetos cotidianos, objetos de familia marcados por destinos individuales pueden terminar en una museografía de historias de vidas. (Re)encontrar los propios bienes, los de la casa natal, en el museo, no es ya una experiencia reservada a los ricos y poderosos y nutre (...) una experiencia contrastada del valor y del uso".

En esta línea podríamos situar el discurso del profesor Paredes (2010) en su artículo Museo pedagógico virtual vivo, donde señala cómo "el conocimiento recogido" es algo inusual en la universidad: vivencias, recuerdos, añoranzas... Se trata de superar conocimientos acabados y aceptar, más humildemente, que el conocimiento es reconstruido de la práctica” (Paredes, 2010: 47). Añado a su definición el concepto de objeto, que va a ser en el que se base nuestro planteamiento, puesto que el museo podemos entenderlo como un contenedor de artefactos aptos para el estudio de muy distintas disciplinas, ya que además de piezas de colección se trata de instrumentos o herramientas al servicio de la educación (Santacana y Mestre, Llonch Molina, 2012; De los Reyes Leoz, 2009; García Blanco, 1999).

El proyecto del Museo Vivo ha escogido un formato de archivo y portátil, y se pone a disposición de todo tipo de público, especialmente de la comunidad universitaria. Responde a la definición de museo que recoge la LPHE 16/1985 en su artículo 59.3, citada al comienzo de este artículo. En este caso se propone el aprendizaje a través de objetos de procedencia diversa que permitan las relaciones interdisciplinares, dado que surge como iniciativa de parte del profesorado del Departamento de Didácticas Especificas de la Facultad de Formación de Profesorado y Educación de la UAM, en concreto, el de historia del arte, desde el convencimiento de las posibilidades educativas de las piezas que constituyen nuestro acervo cultural y artístico. 
El Museo Vivo se integra en el Museo Pedagógico Jesús Asensi, cuyos fondos forman un conjunto de tres colecciones adscritas al Centro de Documentación Infantil y Juvenil, anejo a la Biblioteca de Educación. Forma parte "de una gran cantidad de museos que custodian colecciones muy variadas que tiene como único nexo común haberse creado o usado con fines educativos, integrándolas objetos de carácter histórico pero también contemporáneos, dando contenido a lo que se ha venido a llamar "patrimonio educativo" (Romero Sánchez, 2017:239). Y, en línea con lo señalado por el profesor Paredes (2010), cumple con el concepto de museo pedagógico, como institución que investiga "sobre la realidad educativa a través de distintas evidencias, generalmente artefactos tales como materiales de aula y escolares" (p. 52). Este proyecto se acomete también como un laboratorio de experimentación, tal como se planteaba el referente fundamental de los museos pedagógicos en España: el Museo de Instrucción Primaria, después denominado Museo Pedagógico Nacional, dirigido por Manuel Bartolomé Cossío (Cossio, Rubio, Altamira, 1890: XIX-XXI, Ortega Morales, 2002: 169-187)

Los objetos que van a formar parte de este museo vivo, cumplen con uno de los rasgos de los que hablaba Cossío: lo relevante es la utilidad que aporten al educador, independientemente de su estética o sus aspectos formales (García del Dujo, 1985:134). El objetivo esencial es contribuir al razonamiento del discurso del maestro. En este sentido, lo podríamos relacionar, ciertamente, con libros que forman parte de los fondos del MPJA, y que son una aportación fundamental en la historia de la educación, por ejemplo las lecciones de cosas o manuales de materias relacionadas.

\section{LA ORGANIZACIÓN DEL MUSEO VIVO Y LAS CAJAS DE CARTÓN TEMÁ- TICAS}

A priori, la visión del Museo es unitaria, estructurándose en torno a cajas de igual dimensión y forma. Se trata de una caja de color marrón, denominada CAJA VERDE, a la venta en oficinas de Correos (modelo grande de 390 x280 x190 (CAJAGRA200). Se plantea como contenedor de piezas seleccionadas en relación con una institución, con una ciudad, o agrupadas en función de una temática concreta. La primera de ellas gira en torno a la Real Casa de la Moneda, Fabrica Nacional de Moneda y Timbre (FNMT-RCM, en adelante) y está a medio camino entre el arte y las matemáticas (figura 1).

Lo deseable es que paulatinamente se agreguen otras cajas, con las mismas características, procedentes de otros lugares e instituciones, tanto nacionales como extranjeras. De este modo, se podrán sumar al proyecto todas aquellas personas u organismos que lo deseen presentando "su caja" y siguiendo unos parámetros concretos. Las distintas temáticas pretenden ser exponente de la idea de museo vivo, en el sentido de vivencial y vinculado a la realidad. Y por tanto, con especial atención a la realidad cultural que nos rodea 
y de la que debemos partir. Las cajas pueden estar relacionadas con instituciones y acontecimientos culturales, con exhibiciones temporales de referencia o con edificios, monumentos y creaciones emblemáticas de nuestro patrimonio cultural.

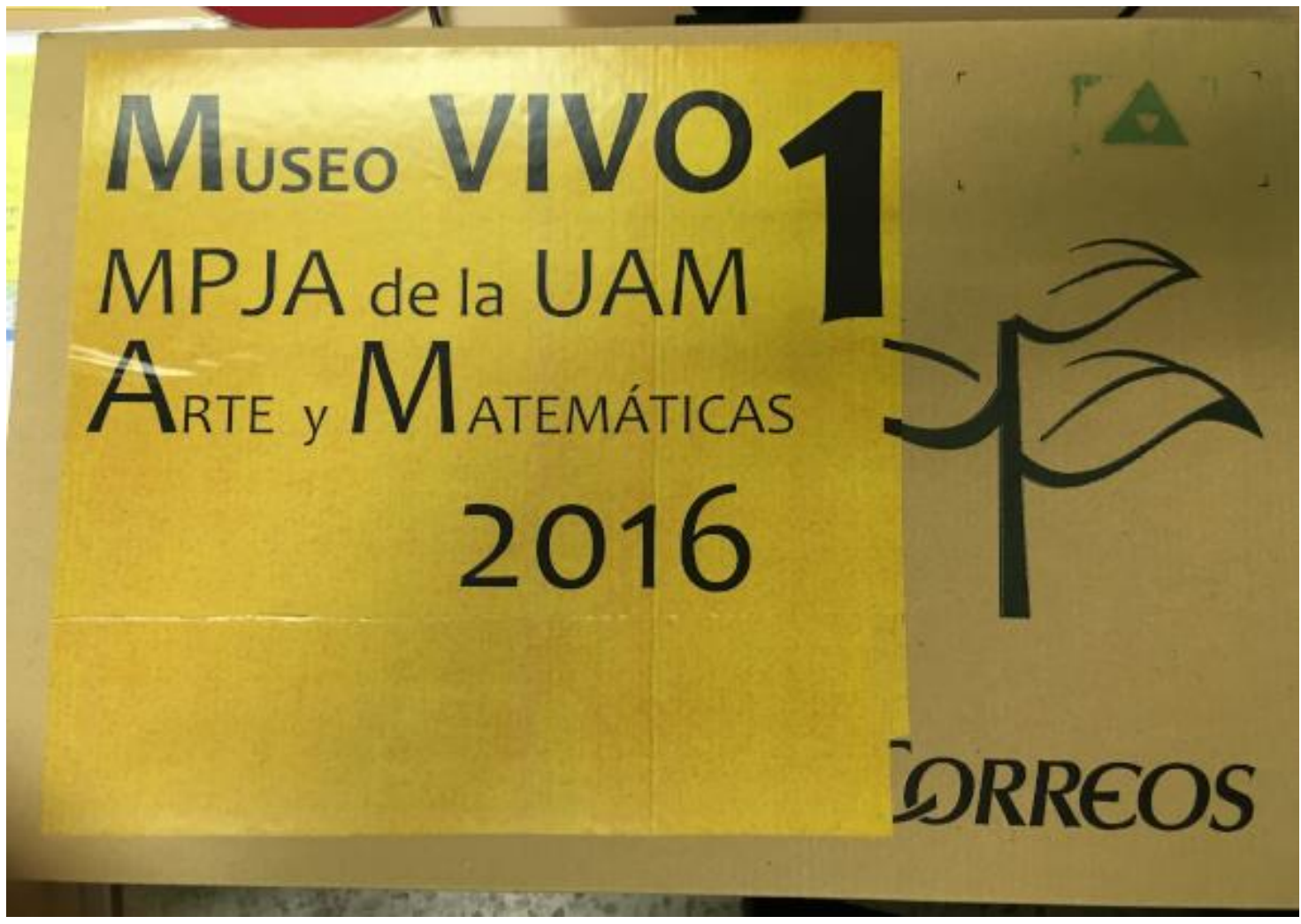

Figura 1. Caja no 1 MuseoVivo MPJA de la UAM. Diseño: Ana Mazoy

El término vivencial vincula también las cajas a la realidad del docente y del estudiante a través de las guías docentes de las asignaturas, en nuestro caso, relativas a las ciencias sociales y su didáctica ${ }^{3}$. Pero también a la realidad cotidiana, al tratar de evidenciar como nuestra vida diaria está plagada de imágenes, objetos y referencias que nos remiten a creaciones artísticas que son parte de un inmenso patrimonio cultural que nos pertenece y que estamos obligados a cuidar y conservar.

Teniendo en cuenta todo esto, la Caja $n^{\circ} 1$ del Museo Vivo surgió a raíz de la muestra Virtuti et Merito, la primera exposición celebrada con motivo del III Centenario del nacimiento de Carlos III en Madrid, en el Museo de la Real Casa de la Moneda, de Madrid (septiembre-noviembre 2016) (figura 2).

\footnotetext{
3 Vid. Grado en Educación Infantil: Conocimiento del medio social y cultural en educación infantil (17024, 3ํocurso); Arte, entorno y patrimonio cultural. La didáctica de los museos artísticos (18820, 4ํㅜㄴono. Mención Arte cultura visual y plástica); Taller del medio social (17050, 4ํㅜㄱso, Mención Conocimiento del medio desde las ciencias y las matemáticas), y Grado en Educación Primaria: Didáctica de las ciencias sociales (17105, $2^{\circ}$ curso); Las ciencias sociales en educación primaria (17096, 2ํㅜ curso); Arte, entorno y patrimonio cultural. La didáctica de los museos artísticos (17130, 4은 curso. Mención Arte cultura visual y plástica), en [Enlace]. Última consulta 8/12/2017.
} 


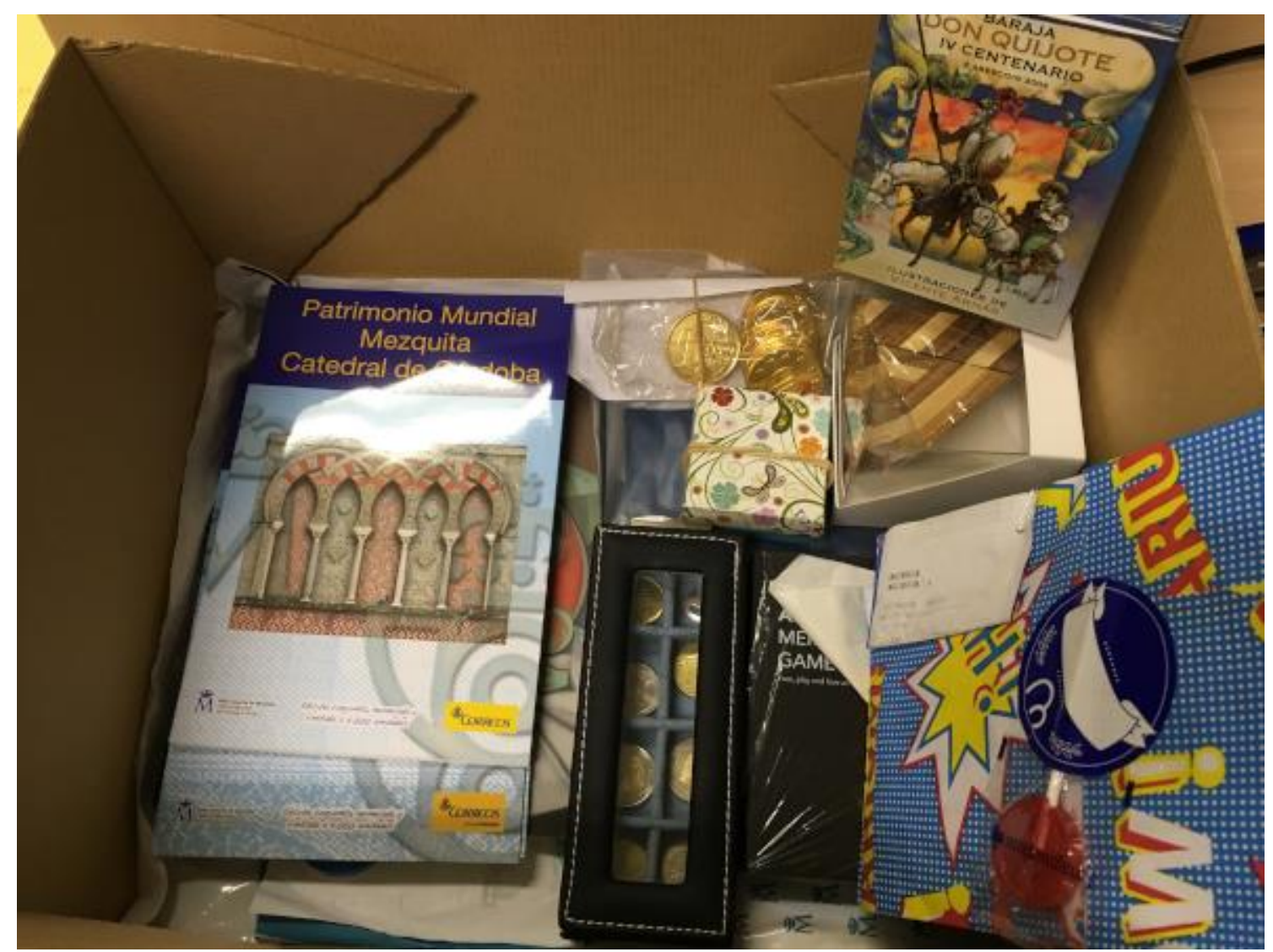

Figura 2. Contenido de la Caja no 1 del Museo Vivo MPJA (UAM).

La segunda caja se ha dedicado a La Alhambra de Granada, y es una aportación del Departamento de Didáctica de las Ciencias Sociales de la Universidad de Granada.

Algunos antecedentes de las cajas en el ámbito de la Historia de la Educación y de la Historia del Arte

La caja, como material educativo, se ha utilizado con diversas finalidades: para fomentar la capacidad de observación, de identificación y exploración, así como la organización, el reparto y la clasificación de objetos, como ocurre con las cajas de distribución utilizadas para la educación infantil, o para la enseñanza de la lectura de los párvulos, caso de las cajas tipográficas o alfabéticas, de las que podemos encontrar información en el Museo Virtual de Historia de la Educación (MUVHE).

El procedimiento de la custodia de documentos o materiales de interés en formato "caja" no es nuevo, no es único de nuestro tiempo, si bien nuestro entorno nos ofrece distintos tipos. Marcel Duchamp creó La boite-en-valise (1935-41): una maleta con sus obras en miniatura que se constituía como un pequeño museo (Cerrolaza, 2018: 82). Por tanto, parece claro que esta idea tiene sentido también en el campo de la creación artística y en el de la cultura y lo interdisciplinar. Así, Andy Warhol a partir de 1974 empezó a realizar un 
trabajo de archivo de todo tipo de objetos y materiales que guardaba en cajas, donde el tiempo quedaba encapsulado: Time capsules ${ }^{4}$ : un registro de su vida, de su trabajo y sus creaciones, contenido en cajas de cartón.

Otros artistas han trabajado y creado con cajas, por ejemplo Joseph Cornell (1903-1972), que desde 1932 las reutilizaba de manera creativa, aunque luego optó por construirlas él mismo en madera y configurar conjuntos de varios objetos: fotografías, cosas de uso cotidiano, textos que cerraba con vidrio en el frente y que obedecían a sus obsesiones, sueños y deseos ${ }^{5}$. Cajas son también las creaciones de Miguel Ángel Blanco de La Biblioteca del Bosque $^{6}$, su gran empeño artístico y vital iniciado en 1985.

Ahora bien, los objetos del Museo Vivo del Departamento de Didácticas Específicas que contendrán las cajas de cartón tiene un objetivo claramente educativo, y está previsto que cuenten con su cartela identificativa y su ficha de catálogo, que tendrá en cuenta el $n^{\circ}$ de inventario o registro, la ubicación, las coordenadas espacio temporales; la fecha de entrada en el museo; el lugar de adquisición y precio; la datación, descripción, nivel educativo y las posibilidades de aplicación didáctica. El proyecto contempla también la presencia de estos objetos en Internet, siendo el medio virtual más versátil a la hora de conformar exposiciones o establecer relaciones entre las mismas, estando a disposición de toda la comunidad educativa y científica.

\section{LA RELACIÓN ENTRE LOS FONDOS DE COLECCIÓN DEL MPJA Y EL PROYECTO DE LA PRIMERA CAJA}

Puesto que el marco de presentación del proyecto fue el MPJA y el tema en el que se centraba el seminario, como señalaba al inicio del texto, era Arte, Monedas y Matemáticas, parecía relevante destacar algunos objetos custodiados en él y relacionarlos con el tema de la nueva caja. Para ello se escogieron algunas publicaciones del área de matemáticas que vamos detallando a continuación.

Por ejemplo, dos publicaciones expuestas en vitrina, ilustradas por Emeterio Ruiz Melendreras (1905-1985), uno de los diseñadores gráficos más potentes del panorama gráfico español del siglo $\mathrm{XX}^{7}$. Son La pintura por el recorte geométrico a base de rectas y curvas y La pintura por el recorte geométrico a base de rectas. Se trata cuadernos que combinan la formación en geometría con las investigaciones educativas sobre la forma y el color. Con ellas, Ruiz Melendreras se alineaba con trabajos destinados a la infancia relacionados con el arte de vanguardia y con los modos educativos propios de métodos activos. Tenían un carácter experimental y estaban formados por una serie de escenas que el niño debía

\footnotetext{
4 Vid. [Enlace]. Última consulta 1/12/21016, en la actualidad esta página no se encuentra operativa); [Enlace]. Última consulta 1/08/2019.

5 Vid. “Joseph Cornell”, en [Enlace]. Última consulta 1/08/2019.

6 Vid. [Enlace] y [Enlace]. Última consulta 2/08/2019.

7 Vid [Enlace]. Última consulta 2/08/2019.
} 
recortar y pegar sobre una hoja de color, con la posibilidad de añadir y quitar formas en las diferentes composiciones, o incluso inventar otras nuevas (Pérez, 1999). Estos materiales se utilizaron en algunos centros de enseñanza, como la Fundación González Allende en Toro, vinculada a la ILE. Tras la guerra, este tipo de actividades se paralizaron en España (Palacio Álvarez, 2008). Ambas publicaciones sugieren la posibilidad de introducir juegos u objetos relacionados con la geometría y la construcción, incluso la arquitectura.

Del mismo modo, los libros de cálculo matemático son una fuente adecuada para encontrar en ellos ilustraciones de monedas, por ejemplo, que suscitan conexiones relacionadas con contenidos propios de las ciencias sociales. De un modo u otro a lo largo de la historia de la enseñanza de las matemáticas, las monedas han mostrado su utilidad. Por ello, se sugieren como ejemplo tres manuales de los fondos del MPJA, aunque las posibilidades son muchas dada la riqueza de los mismos.

El cálculo y el sistema usual de pesas, las medidas y monedas, o la aritmética, evocan un currículo oculto al que se puede sacar mucho partido en relación con otras materias. Así, el libro de José Dalmau Carles: Rudimentos de Aritmética. Libro del alumno destinado a la enseñanza del mecanismo de las operaciones fundamentales aplicadas a los números enteros y decimales, para el Grado Elemental (Dalmau Carles, 1953) que, de una manera esquemática y meridianamente clara, muestra la unidad: la peseta y los valores correspondientes a las monedas de distintos metales.

Asimismo, Lecciones de cálculo, de Aurelio Rodriguez Charentón (s/a), movía a los niños a reflexionar sobre distintos aspectos: el valor de las monedas en relación con las cosas, a distinguirlas con los ojos cerrados; la forma y su porqué; las imágenes o dibujos que presenta la peseta; cómo se hacen las monedas; quién se encarga de hacerlas, y cómo se denominan. También sobre las diferencias de valor según los metales, es decir, sobre el proceso del cambio del dinero. Y todo ello acompañado con imágenes. Se planteaba, por tanto, una enseñanza más allá del valor monetario, que es por donde esta propuesta quiere transcurrir.

Y el texto de Alberto Maillo (1954): Contar y medir. La aritmética del párvulo, que presenta una serie de dibujos en los que se trabaja precisamente ese concepto de seriación y equivalencias. Aunque lo más interesante en cuanto a este trabajo son los dibujos que presentan las monedas: la imagen del jinete a caballo esquematizada, con claras referencias a las monedas ibéricas, tema sobre el que volveremos más adelante, y a la moneda de curso legal entonces.

Los manuales anteriores, que datan de los años cincuenta, lógicamente hacen referencia a la actividad comercial y esto nos da pie a entrar en la temática de la relación con las disciplinas de las ciencias sociales y, en concreto, con la historia del arte y del legado cultural que hemos recibido de nuestros antepasados. Si tratamos de llevar la cuestión a nuestro terreno es indispensable aludir al origen de la moneda, pero deberíamos ir incluso más allá. 


\section{LA CAJA DE LAS MONEDAS: MUSEO VIVO, № 1 (MPJA). POSIBLES TE- MAS DE APLICACIÓN}

En el proceso de enseñanza y aprendizaje que plantea este trabajo, parece importante sugerir distintas temáticas, puesto que nos basamos en una realidad en forma de caja cuyo contenido básico es el objeto "moneda" y otros relacionados que invitan a trabajar sobre distintos aspectos con los alumnos:

\section{La historia de la moneda}

Estamos tan acostumbrados a utilizarla, que nos cuesta plantearnos el origen y su uso inicial. Esto nos remite al trueque, a la actividad comercial y al valor de los metales. La valoración de referencia sería, en un principio, una oveja, un buey, etc., bienes efímeros que generaron la necesidad de concretar el precio, que devino en la sustitución de los recursos por metales. Estos tipos de pagos anticipaban el uso de la moneda (Ortega Galindo, 1947), como instrumento de retribución en cuestiones de salario, de pagos al Estado, en transacciones comerciales o como símbolo de poder y de riqueza ${ }^{8}$.

La sociedad no estaba todavía organizada y fueron los grupos ibéricos los que contribuyeron entre otras cosas al desarrollo del comercio y la moneda. El Museo Arqueológico Nacional (MAN, en adelante) muestra profusa información en este sentido en la exposición de sus colecciones ${ }^{9}$. Podemos utilizar el denario ibérico como fuente documental en distintos sentidos. Es un vestigio de una etapa compleja de nuestra historia en tiempos de la conquista romana, característico de una organización que necesitaba, por su estructura urbana, de la acuñación de moneda. El anverso presenta una cabeza masculina de cabello rizado, antecedente del retrato, y el reverso nos ofrece la figura de un jinete, generalmente lanza en ristre, por lo que desde el punto de vista iconográfico es de enorme importancia ${ }^{10}$. La exposición de este tipo de piezas en el MAN plantea que son objetos que nos hablan de historia, de política, de economía, de vida cotidiana, de religión y cultura ${ }^{11}$. Sin duda, este tipo de objetos son huellas de civilización que han enriquecido nuestro saber y bagaje cultural (MacGregor, 2012: 198-203, 240-246, 316-323, 344-350, 580-586). Desde esta perspectiva, y tratando de llevar el tema a nuestro terreno, es decir el de la historia del arte, podemos ir más allá, pues se trata de algo muy bello elegido por muchos artistas como parte de sus creaciones, otorgándoles a veces un valor moral, estético o histórico.

8 Guía breve, Moneda, Museo Arqueológico Nacional, p. 3 , en [Enlace]. Última consulta 2/08/2019.

9 Guia breve. Protohistoria, Museo Arqueológico Nacional, p. 15, en

[Enlace]. Última consulta 2/08/2019.

10 Vid. Ficha completa no de Inventario 1993/67/1736, Museo Arqueológico Nacional, [Enlace]. Última consulta 2/08/2019.

11 Vid. Guía breve La moneda algo más que dinero, Madrid, Museo Arqueológico Nacional, [Enlace], p. 5, Última consulta 2/08/2019. 


\section{Monedas en la pintura}

Ocurre que la moneda es un objeto frecuente en la pintura de género y en las naturalezas muertas de la pintura flamenca. Respecto a aquella, tenemos un ejemplo significativo, en el Museo del Prado: la obra de Marinus van Reymerswaele, El cambista y su mujer (1539) ${ }^{12}$, en cuya escena aparecen sobre la mesa varias monedas de oro y cobre, junto a una balanza y un libro de cuentas. Sugiere un contenido moral, atribuido a la moneda, en relación con la avaricia, el soborno, la corrupción, etc., y era significativa del contexto de la época, en la que este tipo de profesión era bastante nueva y los cuadros que protagonizaban no solían ser encargos de comitentes, sino que se hacían para vender y en ellos iba implícita la enseñanza moral (De Rink, 2005: 120-21).

El otro género pictórico importante en los Países Bajos en el siglo XVII es el bodegón. La pintora Clara Peeters (act. 1607-1621) refleja el apogeo comercial y cultural de la ciudad de Amberes. En su obra, el significado simbólico atribuido en el siglo pasado a los bodegones, no era tan evidente. Lo que se valoraba era la habilidad del artista para disponer ante la vista de clientes, aficionados y espectadores, preciosos y apetecibles objetos cotidianos (Vergara, 2016: 34-35). Se unen dos aspectos muy significativos relativos a las monedas: el valor formal como objeto bello y su valor como documento histórico que aporta información en cuanto a datación en numerosas ocasiones o es reveladora de modos de vida de tiempos pasados (Vergara, 2016: 31-44).

Se pude concluir, respecto a este punto, que la moneda nos invita a la visita a dos grandes museos madrileños: Museo Nacional del Prado y Museo Arqueológico Nacional.

\section{LAS MONEDAS HABLAN}

Por otra parte, las imágenes acuñadas en nuestras monedas nos transmiten acontecimientos, valores, gustos y numerosos datos sobre la historia de nuestro país. Brevemente merece destacar, en este sentido, el contexto en el que se editan los manuales de cálculo sobre los que trabajamos: mediados del siglo XX. Así, por ejemplo, durante la Guerra Civil la escasez de metales (plata y cobre) hizo que fueran requisadas y que se recomendara la utilización del cartón. En 1938, mediante el Decreto de 24 de diciembre, se facultaba al Ministerio de Hacienda y Economía para utilizar la llamada moneda-sello, de discos rígidos de cartón con el escudo de la República en anverso y un sello de correos en el reverso (Miró Argulló, 2009: 465-468) ${ }^{13}$. Esto nos permite introducir el concepto de Moneda y Timbre, también acorde con los objetos de la Caja del Museo Vivo. La Fábrica Nacional de Moneda y Timbre nacía en 1893 cuando se fusionaban dos organismos: La Casa de la Moneda y la Fábrica del Sello y da lugar a la Fábrica Nacional de Moneda y Timbre - Real Casa de la Moneda (FNMT-RCM, a partir de aquí) que, como empresa de servicio público,

12 Vid. [Enlace], Última consulta 2/08/2019.

13 Vid. Historia de las monedas: historia de la peseta, en [Enlace]. Última consulta 3/08/2019. 
produce monedas, billetes, timbres y documentos oficiales, y es también testimonio y documento de distintas facetas de nuestra historia y nuestra cultura. Cuando terminó la guerra civil se acuñaron entre 1940 y 1953, monedas de cinco y diez céntimos, cuyo diseño en el anverso recuerda las emisiones de moneda ibérica, con el jinete con lanza sobre el caballo al galope.

En 1947 empezó a utilizarse el busto de Franco en el anverso. Ya en 1975 se acuñaron monedas con la imagen del rey Juan Carlos que se utilizaban junto con las anteriores. En 1982 se empezaron a incluir en los diseños acontecimientos culturales, como el Campeonato Mundial de Futbol, lo que dio lugar a que en los años noventa las imágenes de los gobernantes coexistían con las de efemérides, acontecimientos culturales, personajes célebres o representaciones del patrimonio cultural significativas de cada Comunidad Autónoma ${ }^{14}$.

\section{El patrimonio de mano en mano}

Las imágenes, en numerosas ocasiones, son más poderosas que las palabras, y parece que las más potentes son las que vemos tan a menudo que apenas reparamos en ellas, caso de las monedas. Los gobiernos son los que dan forma al dinero y emiten mensajes a través de él. Mensajes efectivos que pueden perdurar en el tiempo, incluso más allá de la muerte de los gobernantes.

Las monedas de cincuenta pesetas, en los años noventa (1989-2001) abrieron las fronteras españolas hacía las corrientes europeas. Se utilizaron imágenes de bienes del patrimonio español de enorme proyección internacional: con motivo de la Exposición Universal de Sevilla de 1992 se eligió para las monedas de veinticinco pesetas el Monasterio de la Cartuja, la Giralda y la Torre del Oro.

Para la celebración de los Juegos Olímpicos de Barcelona en 1992, se acuñaron monedas de cincuenta pesetas con las imágenes del Templo Expiatorio de la Sagrada Familia y La Pedrera, de Gaudí. En años sucesivos se incluyeron bienes patrimoniales de las distintas comunidades autónomas.

Desde 1993, se acuñaron en monedas de doscientas pesetas imágenes de obras muy significativas de la historia de la pintura: Las Meninas, de Velázquez, El Quitasol, de Goya (1994); San Mauricio y la Legión Tebana, de El Greco; El Buen Pastor, de Murillo (1995); El Majo de la guitarra, de Goya, e Idilio, de Fortuny (1996).

A partir del cambio de la peseta al euro en el sistema monetario europeo, el euro es la moneda vigente y única en España y el resto de la Unión Europea desde el año 2002. Se distinguen tres tipos de monedas: las de curso legal o en circulación en toda la zona euro; las monedas conmemorativas, también para la circulación pero con aprobación previa del

14 Vid. “Historia de las monedas: historia de la peseta”, en [Enlace]. Última consulta 1/12/2017; [Enlace] 
Banco Central Europeo y diseños susceptibles de cambio cada año y sólo objeto de acuñación en la modalidad de dos euros; y las monedas de colección, que no son de curso legal (aunque pueden serlo en el país emisor). Su tirada es limitada, por lo que no suelen utilizarse en lo cotidiano.

Desde 2002 podemos constatar la presencia constante de motivos del patrimonio cultural español en las emisiones de moneda, pues como se indica en la Orden ECO/931/2002:

"La aparición de la moneda única europea, el euro, no resulta incompatible con la acuñación de monedas en euros, cuya finalidad principal no sea la de medio de pago sino la difusión cultural y artística o la conmemoración de acontecimientos de cierta transcendencia" ${ }^{\prime 15}$.

España presidía entonces la UE en el primer semestre de aquel año y para conmemorarlo se procedió a la emisión, acuñación y puesta en circulación de monedas conmemorativas. Es decir, esto es un ejemplo de que se entiende la moneda como un medio de divulgación de nuestra cultura y patrimonio, aspecto que es inherente a ella desde tiempos remotos, pues entonces era el único objeto de uso cotidiano producido en serie y constituía un instrumento para transmitir cómo se veían a sí mismos los gobernantes, la sociedad o el país de origen. O lo que es lo mismo, un instrumento muy potente de difusión que aún se mantiene en nuestros días.

Un repaso de las emisiones de moneda protagonizadas por imágenes del patrimonio cultural español con motivo del cambio de moneda, parece significativo:

En 1999 se realizó el diseño para el conjunto de las monedas que se emitirían en España con motivo del cambio al euro. Se escogía la imagen de la Fachada del Obradoiro de la Catedral de Santiago de Compostela para las de uno, dos y cinco céntimos, que todavía hoy siguen de mano en mano.

En cuanto a las monedas conmemorativas, una las motivaciones para su emisión es la puesta en valor de nuestro patrimonio y sus bienes más significativos, a causa de la celebración de un acontecimiento cultural a nivel mundial, caso del Año Internacional Gaudí (2002, el Centenario del nacimiento de Salvador Dalí (2003), o el Año Santo Xacobeo, que reproduce la efigie de Santiago del parteluz del Pórtico de la Gloria y una concha de peregrino $(2004)^{16}$.

A partir de 2010 y motivado por la cuarta emisión de moneda de dos euros, España quiso "rendir tributo a los bienes y lugares inscritos en la lista del Patrimonio Mundial de la UNESCO, con la emisión anual de una moneda conmemorativa de 2 euros. El pertenecer a esta lista significa que los bienes estarán protegidos y que se preservarán.

15 Vid. “ORDEN ECO/931/2002, de 17 de abril, por la que se acuerda la emisión, acuñación y puesta en circulación de monedas conmemorativas de la Presidencia Española de la Unión”, en BOE núm 103, Madrid, Ministerio de Economía, 30/04/2002, p. 15739.

16 Vid. [Enlace] . Última consulta 10/12/2017. 
La primera moneda de esta serie emitida en el año 2010, está dedicada al Centro Histórico de Córdoba, y en concreto, a la Mezquita Catedral de Córdoba"17. Se inauguraba así una serie anual importante para este trabajo en la que se incluirían los bienes más importantes declarados Patrimonio de la Humanidad en nuestro país. En el reverso de la moneda aparece la doble arquería del interior de la Mezquita Catedral de Córdoba (una moneda de esta serie se incluye en la Caja $n^{\circ} 1$ del Museo Vivo) (figuras 3 y 4).

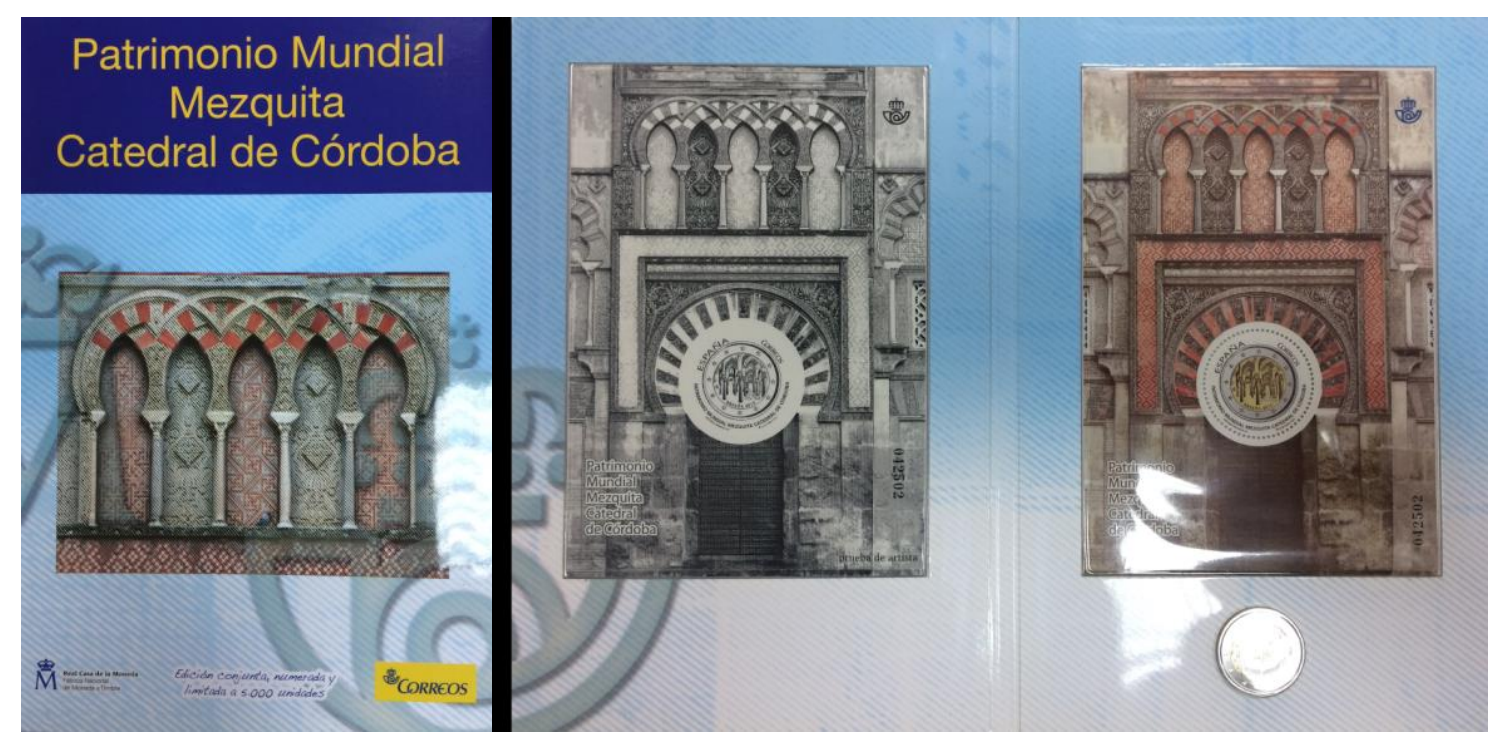

Figura 3 y 4 (de izq. a der). Estuche de la moneda conmemorativa de dos euros: Mezquita Catedral de Córdoba (FNMT-RCM) e Interior del estuche de la moneda conmemorativa de dos euros de la Mezquita Catedral de Cordoba. Contiene: sello en hoja bloque, prueba de artista y moneda (FNMT-RCM).

En emisiones sucesivas aparecen el Patio de los Leones de la Alhambra de Granada (2011) (también la moneda de esta serie forma parte de la Caja ${ }^{\circ} 1$ del Museo Vivo); la Catedral de Burgos (2012), el Real Monasterio de San Lorenzo de El Escorial (2013); el Parque Güell (2014); el Acueducto de Segovia (2016); Santa María del Naranco (Oviedo, Asturias) (2017) , y finalmente, para 2018 se preveía la emisión de la moneda conmemorativa del Centro Histórico de Santiago de Compostela ${ }^{18}$.

En el año 2008 se hace una emisión de la I Serie Pintores Españoles, dedicada a Velázquez. A partir de entonces se han sucedido diversas series, que por su extensión y por motivos de espacio simplemente se citan: la continuación de la Serie Pintores Españoles y las dedicadas a Patrimonio Nacional, Tesoros Museos Españoles (la última está dedicada

\footnotetext{
17 Vid. “2 Euros Proof-Córdoba”, en [Enlace]. Última consulta 7/12/2017.

18 Véanse las distintas emisiones de monedas conmemorativas en [Enlace], donde se dice lo siguiente: "La adquisición de moneda de colección va más allá del puro coleccionismo. Por una parte se adquiere un producto de valor reconocido. Por otra, se guarda un fragmento de historia y de los acontecimientos más representativos plasmados en las diferentes piezas". Última consulta 7/12/2017.
} 
en este año 2019 al Bicentenario del Museo del Prado), y Ciudades Patrimonio de la $\mathrm{Hu}-$ manidad $^{19}$.

Todas estas son monedas de colección. Es decir, estamos considerando la moneda como lo que lleva siendo desde hace siglos: una pieza que es objeto de deseo para configurar un conjunto y para su inclusión en el museo.

También, en este caso, debemos recordar los antecedentes: la existencia de los llamados monetarios en las colecciones de la Corona, que dieron lugar, junto con otros objetos, al Museo de Medallas y Antigüedades, hoy Museo Arqueológico Nacional, que tiene su origen en la Real Librería de Felipe V (Otero Morán, 2016: 30-34). En este museo inicial, las monedas se guardaban en los monetarios, que la RAE define como el "conjunto de estantes cajones o tablas en que están colocadas ordenadamente las monedas y medallas", si bien también nos ofrece la acepción siguiente: "la colección ordenada de monedas y medallas".

Merece especial mención como contenedor, en este caso, el Monetario de don Gabriel de Borbón, hijo de Carlos III y María Amalia de Sajonia, que pertenecía a los fondos fundacionales del MAN y cuya organización era perfecta: un mueble distribuido en veintiún tablas forradas en terciopelo, con los huecos hechos en el tamaño de las monedas y con indicaciones en cuanto al origen y características de las mismas. Es decir, podríamos calificarlo como de pequeño museo o como de caja muy ilustrada (Gómez Talavera, 2014). ${ }^{20}$

La colección numismática del Museo de la Real Biblioteca la formaban un monetario grande y doce pequeños y los fondos actuales del MAN están considerados como los más importantes de España y de Europa. Uno de los objetivos de esta institución desde el punto de vista museológico es mostrar el conjunto de las monedas como una parte esencial del legado que hemos recibido del pasado y de nuestro patrimonio contemporáneo ${ }^{21}$. Para ello se ha creado en el nuevo montaje museográfico un espacio ex novo que merece tener en consideración para el conocimiento de nuestros alumnos Es el primer montaje que presenta la moneda con "un planteamiento temático, no cronológico; se trata de acercar a un público profano el mundo de los objetos numismáticos como los documentos históricos que son, contextualizando las piezas y poniendo de relieve toda la valiosa información arqueológica, social, tecnológica, cultural, económica, artística, política, simbólica... que aportan” (Grañeda Miñón, 2014: 564).

Nuevamente esta información nos facilita y sugiere trabajos con los alumnos, como podría ser la organización de un monetario en clase, con piezas llevadas por ellos mismos que muestren figuras significativas del legado cultural español, con lo cual implicaríamos a los niños, pero también a las familias y, sin duda, la visita al MAN al montaje museográfico sobre la moneda.

\footnotetext{
19 Véase información sobre las distintas series en [Enlace]. Última consulta 14/08/2019.

20 Vid. "Monetario, № Inv. 1984/130/35". Accesible en [Enlace]. Última consulta 6/07/2019.

21 Vid. Guía breve, Moneda. Madrid: Museo Arqueológico Nacional, p. 3, en [Enlace]. Última consulta 8/07/2019.
} 


\section{EL CONTENIDO DE LA CAJA № 1 DEL MUSEO VIVO DE HISTORIA DEL ARTE}

Todo museo tiene un mensaje que contar, en su colección permanente y en sus exposiciones temporales. El Museo Vivo tiene un relato y una misión que hemos contado al inicio, pero cada caja podría equivaler a una sala del museo como institución tradicional, es decir, tiene un discurso concreto. ¿Cuál es el de esta caja?: Monedas y objetos relacionados para utilizar como instrumento educativo para la enseñanza de la Historia del Arte. Ahora bien, éste mensaje viene dado, evidentemente, por la relación de las piezas contenidas en ella, que distinguimos en dos aspectos:

Piezas de carácter gratuito:

1. Dos carteles de las emisiones de monedas de euro cuya temática son los bienes Patrimonio de la Humanidad, enfatizando las ciudades que tiene proyección universal, lo que indica que entrábamos al inicio el siglo XXI en una nueva era y una nueva dimensión: la europea. El tema central de este objeto es la puesta en valor de los bienes patrimoniales declarados por la UNESCO (figura 5).

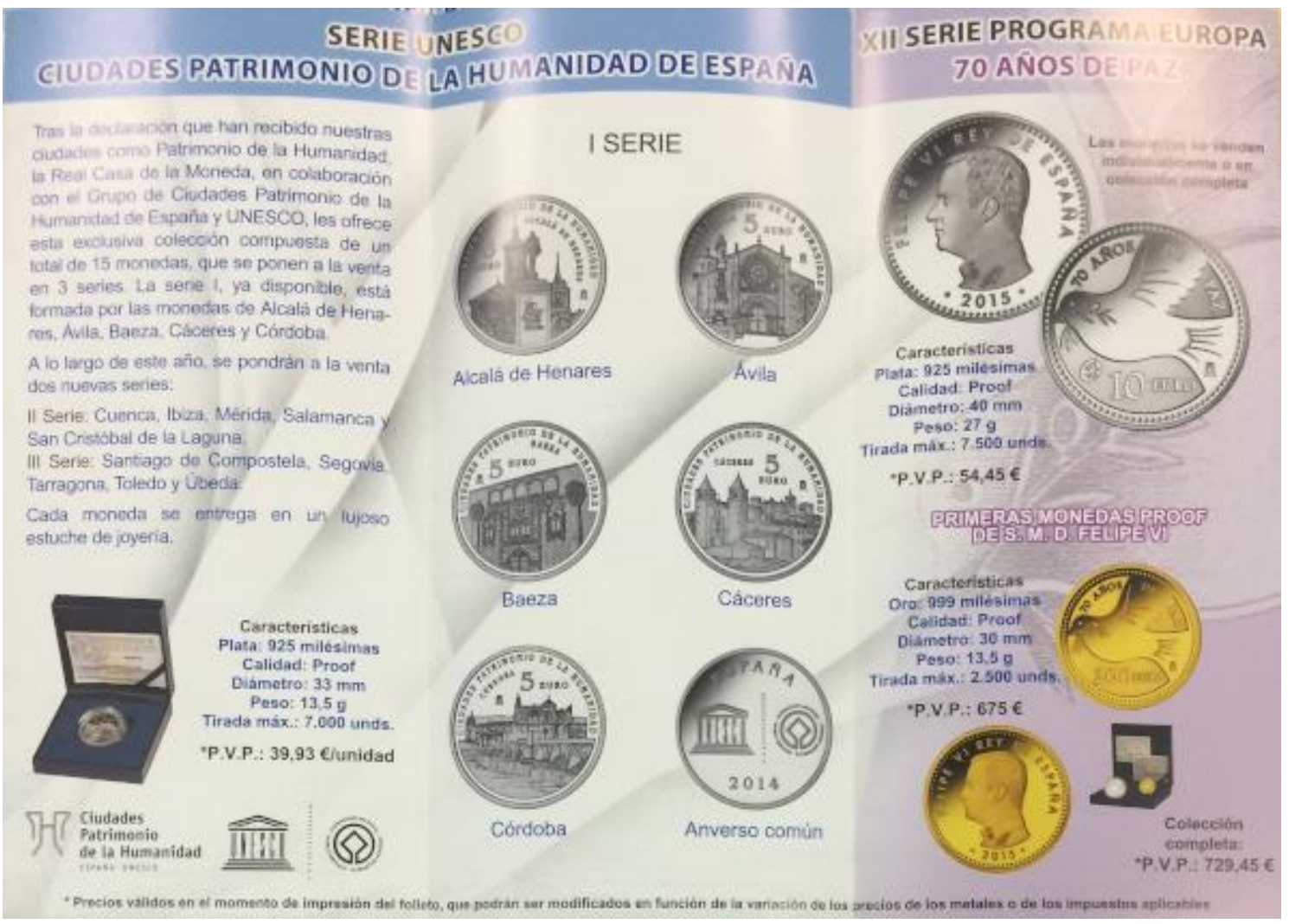

Figura 5. Cartel Serie UNESCO Patrimonio de la Humanidad de España (FNMT-RCM). 
2. Folletos informativos relacionados con lo anterior.

3. La bolsa de la tienda del museo por su interés simbólico, pues en ella observamos la imagen del tórculo que nos facilita la explicación sobre la fabricación de la moneda (figura 6).

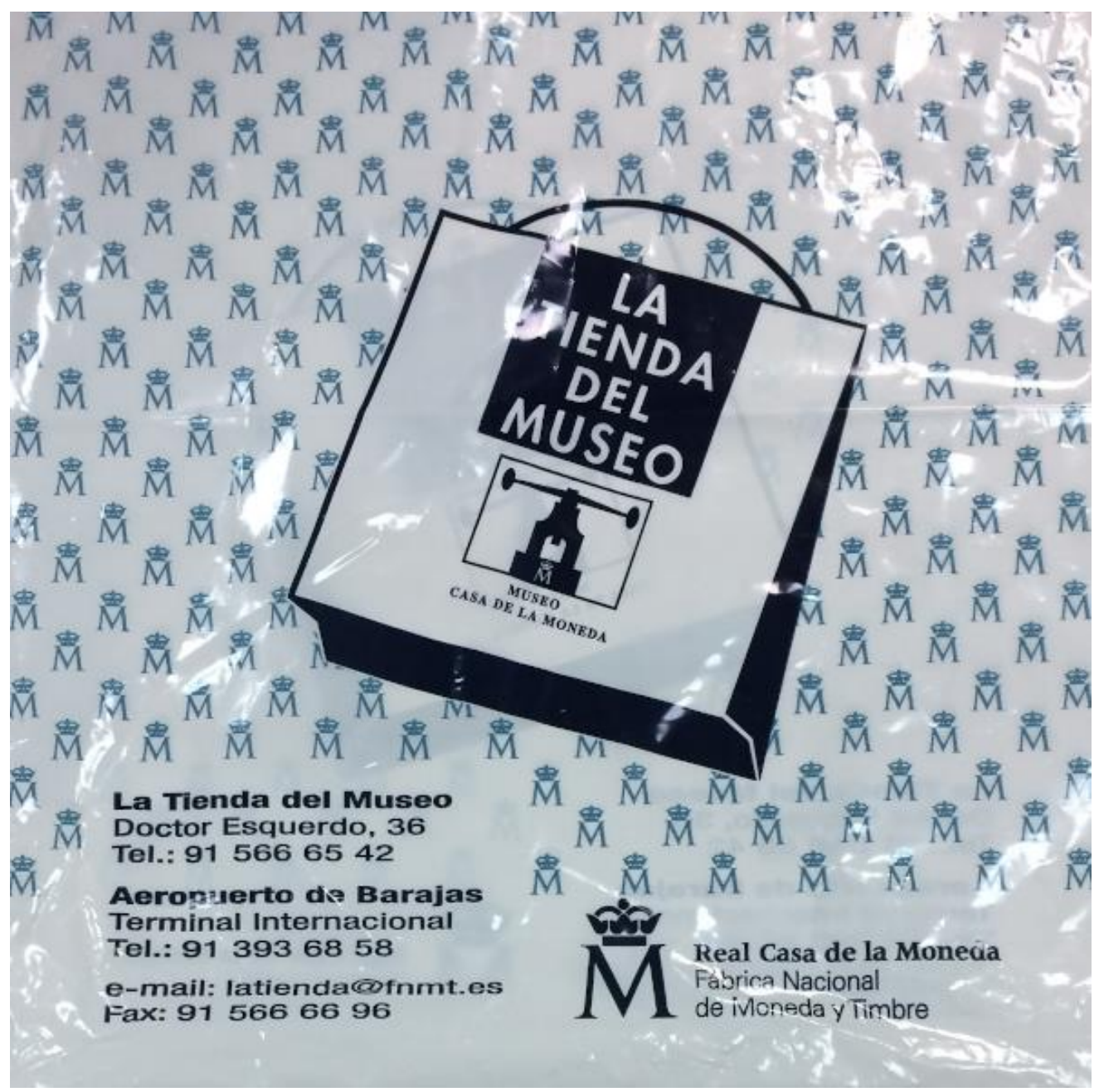

Figura 6. Bolsa de la tienda del Museo Casa de la Moneda (FNMT-RCM).

Piezas adquiridas:

1. El libro El turismo y el arte, necesario para la transferencia de conocimientos, en relación con el currículo y las guías y programas docentes. Son especialmente significativas las páginas dedicadas a los grabados en los que se basan las imágenes, las de grabados y monedas, y las de sellos y monedas (De Quesada, 2013: 70-73; 86-93 y 126-137). Todo ello en el contexto de la relación del turismo con la moneda, por lo que los ejemplos de objetos alusivos a la riqueza del patrimonio cultural español son una constante. 
2. Monedas de colección a partir de las que podemos establecer un discurso histórico artístico, del que aquí aportamos tres emblemas del conjunto de bienes de interés cultural: la Cuevas de Altamira, la Mezquita de Córdoba y la Alhambra de Granada.

3. Colección de sellos oficiales que presentan distintas imágenes de la historia del arte español: obras de Picasso, cuya fecha de emisión fue el 29 septiembre 1978: Retrato de la señora Canals, Autorretrato, Retrato de Jaime Sabartés, El final del número, Ciencia y Caridad, Las Meninas, Los Pichones, y El Pintor y la Modelo (figura 7); el Patio de los Leones de la Alhambra de Granada, de 1964; el sello con la imagen de El Partal y la Torres de las Damas, de la Alhambra, o la emisión de sellos de 1962 en honor a Pedro Pablo Rubens: Don Fernando de Austria pintado por Rubens (figura 8).
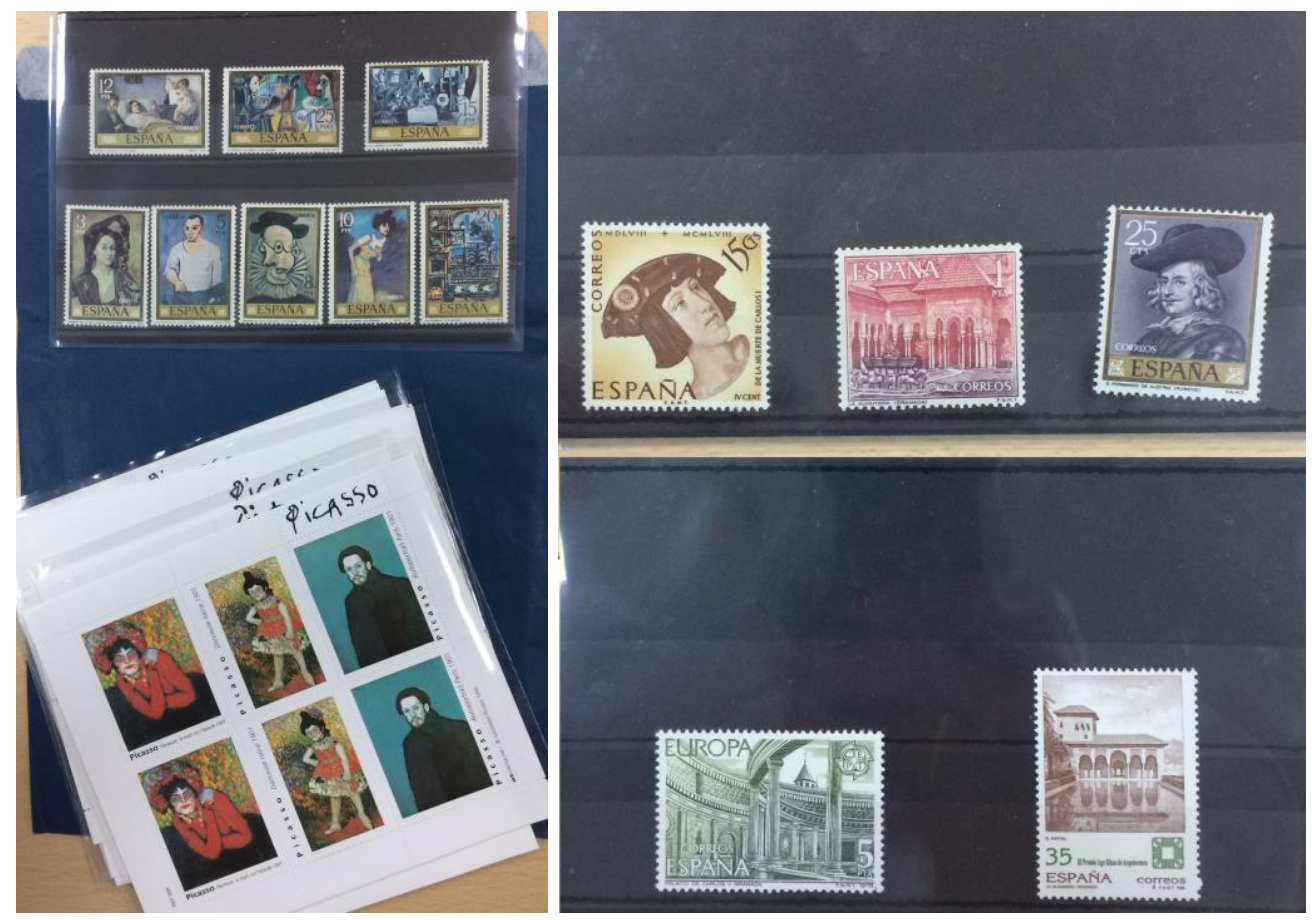

Figura 7 y 8 (de izq. a der). Sellos oficiales de obras de Picasso (26/09/78) y colección de sellos divulgativos a la venta en el Museo Picasso de Barcelona I Sellos oficiales de colección (1962, 1964 y 1998).

Todos los temas que aparecen en ellos nos permiten trabajar sobre el arte del grabado y el proceso de elaboración de las monedas, así como sobre la Fábrica de Moneda y Timbre, y sobre la importancia de estos monumentos u obras en la evolución del arte español. El sello siempre ha estado vinculado al turismo (postales), a la moneda y al patrimonio y la historia del arte. 
4. Sellos divulgativos y coleccionables con imágenes de pintura y grabados de la colección del Museo Picasso de Barcelona, comprados en la tienda del museo.

5. La baraja de El Quijote: esta caja atiende al entorno del niño, sobre lo que se hace hincapié en los programas docentes de Infantil y Primaria. Esta edición (2004) de la baraja española con ilustraciones de Vicente Arnás Lozano (1949) presenta, lógicamente, las figuras de los "oros" o monedas de la baraja, algo con lo que el niño juega, bien en casa, en el colegio, o con sus amigos, y lo conoce bien (figura 9).

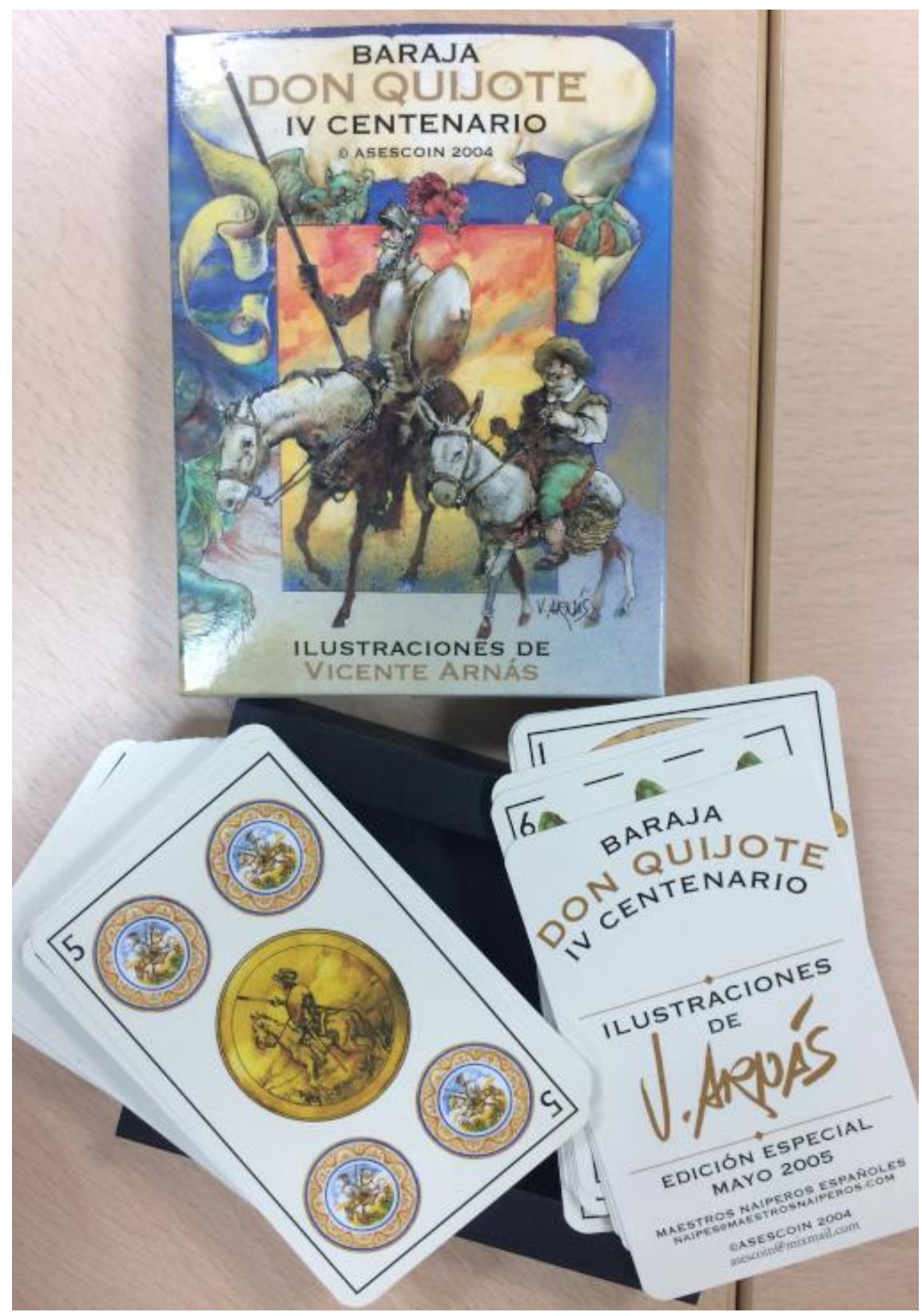

Figura 9. Baraja Don Quijote IV Centenario. Ilustraciones de Vicente Arnás. Edición especial 2005, Asescoin, 2004. 
6. Monedas de chocolate y la bolsa del dinero, en la misma línea de lo anterior. La caja contiene una moneda del Vasa Museet, el museo más visitado de Estocolmo y de Suecia. Con un solo bien que mostrar: el barco del siglo XVII, recuperado de la bahía de Estocolmo y restaurado. Su imagen es el logo del museo, como se aprecia en la moneda de chocolate 22 (figura 10). Se ha incluido, asimismo, el juego o bolsa de las monedas de Imaginarium (figura 11), y alguna moneda de las tiendas de chucherías.

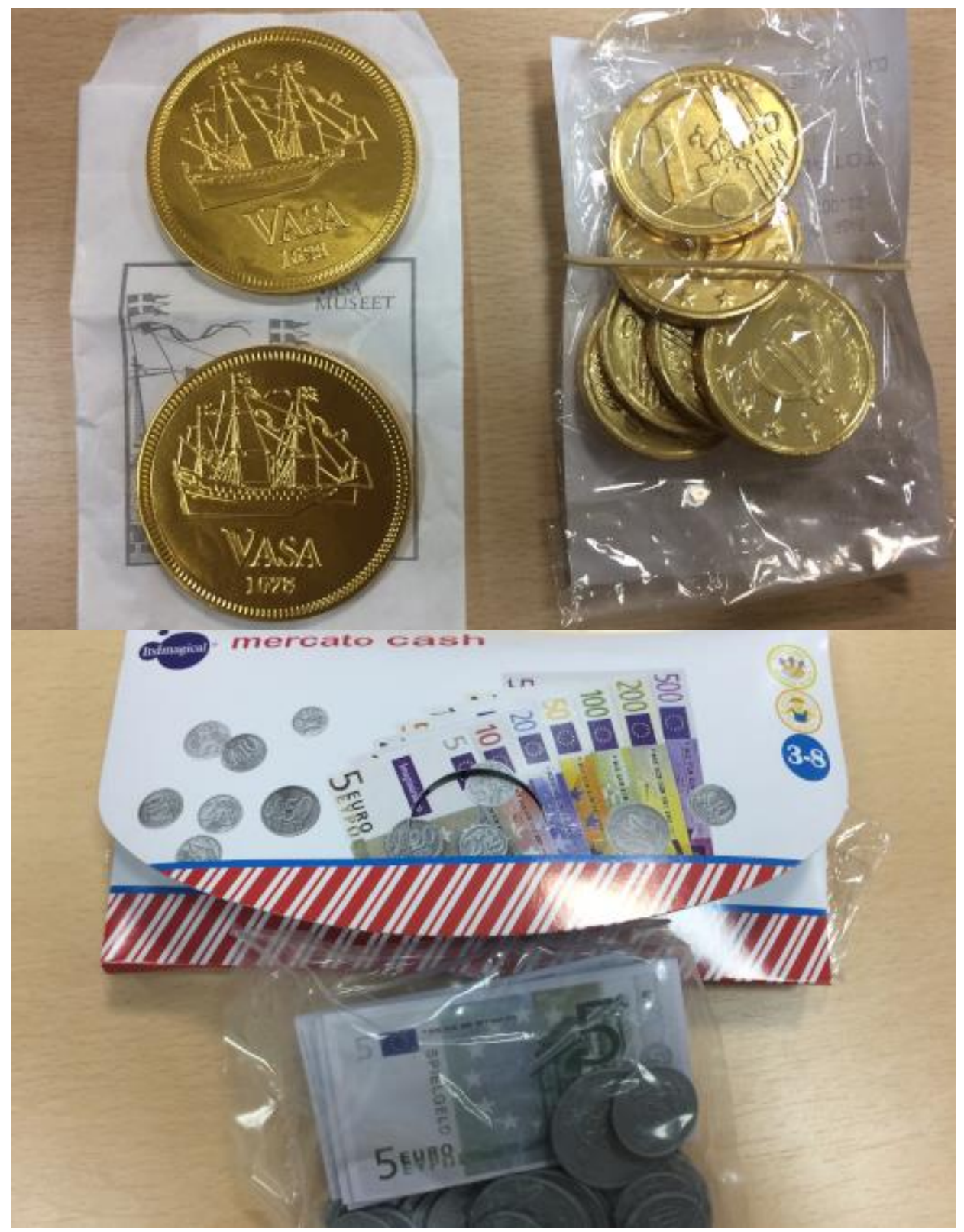

Figura 10 y 11 (de arriba abajo). Moneda de chocolate del Vasa Museet (Estocolmo) y monedas de chocolate de un euro | La bolsa del dinero, Imaginarium.

22 Vid. [Enlace] (última consulta 8/08/2019) 
7. Puzle 1Q. Juego de inteligencia: Pirámide de piezas de madera, que podemos relacionar con los cuadernos y manuales de geometría y con la historia de la arquitectura.

Tanto la baraja, como las monedas de chocolate, como la bolsa de billetes y monedas de juguete, vinculan el arte y el juego, algo inherente al mundo de los niños, sobre lo que se hace hincapié en los programas docentes de EI y EP, que debe tenerse en cuenta por su importancia.

8. El pequeño monetario de la Caja $\mathrm{n}^{\circ}$ 1: monedas en circulación que reproducen obras de arte emblemáticas de distintos lugares y países (figura 12 y 13):
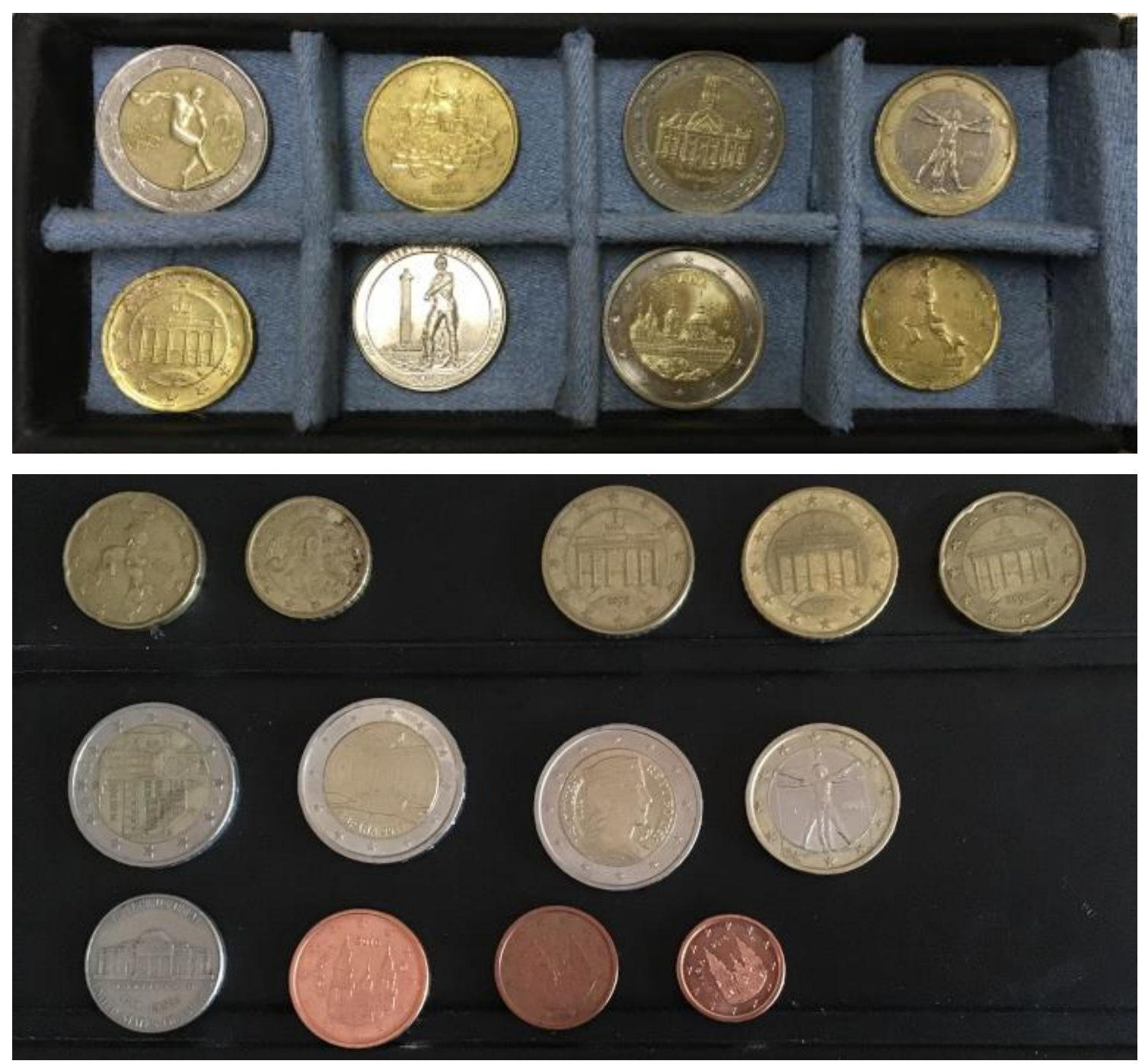

Figura 12 y 13 (de arriba abajo). Pequeño monetario de la Caja no 1 Museo Vivo.

a) Mirón, Discóbolo, c. 450 a.C., Grecia 2004 (2 euros).

b) El Patio de los Leones de la Alhambra (1354-1391) (2 euros). 
c) Ayuntamiento de Bremen (c. 1405-1410), con la Estatua de Rolando (1404), en primer plano. Ambos declarados Patrimonio de la Humanidad por la UNESCO (2 euros).

d) Sandro Boticelli, El Nacimiento de Venus (1484-85). Se reproduce el rostro de Venus (10 céntimos de euro).

e) Leonardo da Vinci, Hombre de Vitrubio, 1485-1490. Italia, 2003, y 2009 (1 euro).

f) Miguel Ángel, Plaza del Campidoglio de Roma (1563-1564), con la Estatua ecuestre de Marco Aurelio (c.166) en el centro, Italia 2002 (50 céntimos).

g) Juan de Herrera, Monasterio de San Lorenzo de El Escorial, (1562-1584), España, 2013 (2 euros).

h) Fachada del Obradoiro de la Catedral de Santiago de Compostela, obra de Fernando de Casas y Novoa (1738-1750) (1, 2 y 5 céntimos).

i) Iglesia de San Luis, símbolo de Saarbrücken, capital del Sarre (Alemania). Fachada este y campanario. Finalizada en el siglo XVIII. Alemania, 2009 (2 euros).

j) Edificio Residencia de Thomas Jefferson, denominada Monticello (17681809) y diseñada por él mismo (Estado de Virginia, EEUU). Declarada Patrimonio de la Humanidad por la UNESCO EEUU (5 centavos de dólar).

k) La Puerta de Brandeburgo (Berlín), obra del arquitecto Carl Gotthard (1788-1791), Alemania, 2000 (50 y 20 céntimos).

1) Umberto Boccioni, Formas únicas de continuidad en el espacio (1913), Italia, 2003 (20 céntimos).

m) Perry's Victory and International Peace Memorial, Put-in-Bay, Ohio, 1912-1915, EEUU, 2013 (Cuarto de dolar). Se trata de una moneda conmemorativa acuñada en el contexto del America's Beautiful National Parks Quarter Dollar coin program, que se inició en 2010 y se extenderá hasta 2021 (Cuarto de dólar).

n) Retrato de una joven letona, basado en el retrato del artista letón Rihards Zarins de la joven Zelma Brauere (c. 1929) que simboliza a la República de Letonia y la libertad y que figuraba en el reverso de las monedas de 5 lasts en 1929. Letonia, 2014 (2 euros $)^{23}$.

9. Los periódicos del día en que se presentó el proyecto: 17/11/2016. Se han incluido las ediciones de El Mundo, El País, ABC y La Razón.

23 Vid "Moneda de 5 lats", en [Enlace]. Última consulta 8/08/2019) 
Todas las representaciones escogidas que aparecen en estas monedas nos permiten casi hacer un recorrido por la historia del arte y sus estilos y movimientos. Desde el arte clásico griego y romano con las esculturas del Díscóbolo de Mirón y la Estatua ecuestre de Marco Aurelio, el arte nazarita medieval con el Patio de los Leones de la Alhambra; el arte del Renacimiento, a través de obras de Leonardo, Boticelli, Miguel Ángel y Juan de Herrera; la arquitectura barroca en la fachada del Obradoiro y la LudwigsKirche; la arquitectura neopalladiana de la casa Monticello y el historicismo de la Puerta de Brandeburgo, o las aportaciones del arte de vanguardia a partir de la escultura de Boccioni.

Si añadimos a éstas el sello del bisonte de Altamira, la moneda conmemorativa de la Mezquita de Córdoba, los sellos basados en la arquitectura nazarí y renacentista (Palacio de Carlos V de Granada), la pintura barroca de Rubens y la obra de Picasso, abarcaríamos un arco temporal que va desde la Prehistoria hasta la pintura de los años sesenta (El pintor y la modelo y Las Meninas, de Picasso) Al menos sirven para introducirlos y hacer ver a los alumnos cómo estas imágenes, que corren de mano en mano, hacen que no nos olvidemos de las creaciones de nuestros antepasados, que su paso y permanencia a través de generaciones les convierte en testigos de nuestra historia, en representaciones de ésta, y por ello forman parte de la identidad de un pueblo y generan orgullo y autoestima.

Por otra parte, la mayor parte de las obras de arte y monumentos elegidos para la acuñación de monedas los encontramos en los manuales de texto, al tratarse de obras señeras del patrimonio cultural español europeo o mundial. No cabe siquiera citar aquí algunos ejemplos significativos y relativos al Grado de Primaria, pero podemos señalar esto como una vía de trabajo de enorme interés en el panorama educativo.

\section{REFLEXIÓN FINAL}

La Caja ${ }^{\circ} 1$ del Museo Vivo del Departamento de Didácticas Específicas de la UAM, es, de momento, una síntesis de la idea de lo que se pretende mediante la utilización de conceptos y de un lenguaje que son propios de nuestro tiempo:

- Desde la sencillez y la economía de medios, se alinea con nuevos formatos vinculados a las transformaciones de la museología contemporánea y con los planteamientos más recientes de trabajo en relación con los museos pedagógicos.

- Presenta un planteamiento pedagógico basado en el aprendizaje a través de los objetos y en la idea de los puntos de encuentro y lo transversal entre materias distintas de los currículos de Educación Infantil y de Primaria, que puede hacerse extensivo a la Enseñanza Secundaria Obligatoria y el Bachillerato.

- Es una propuesta abierta y en continuo proceso de realización, como es propio y característico de la idea de museo, acorde con las nuevas tendencias museológicas y los cuestionamientos en relación con el papel educativo del museo, así como con la revitalización de los museos universitarios. 
- Supone una herramienta educativa para la didáctica de la Historia del Arte que quiere poner en conexión la propia vida con las manifestaciones artísticas heredadas de nuestros antepasados.

- Actúa como un recurso que posibilita la enseñanza de contenidos relativos a la Historia del Arte, de los procesos técnicos de creación de las obras y del potencial comunicativo de las imágenes artísticas.

- Plantea, en definitiva, una forma de aprendizaje que incide en el conocimiento del Patrimonio Cultural, enfocado a la comprensión, valoración, conservación protección, cuidado y disfrute de los bienes culturales que hemos recibido y debemos preservar para las futuras generaciones y es, por tanto, acorde con los planteamientos del Plan Nacional de Educación y Patrimonio (CARRIÓN GUTIEZ, 2015).

En definitiva, y de momento, un proyecto que se hace visible en una caja, un plan en proceso, con unas posibilidades educativas que trascienden a los objetos que la integran y que invitan a extenderlo y hacerlo factible para conseguir el impulso necesario para la mejora de la enseñanza y el aprendizaje de la Historia del Arte.

\section{REFERENCIAS}

ALONSO FERNANDEZ, L. (1999): Introducción a la nueva museología. Madrid: Alianza Editorial.

ÁLVAREZ DOMÍNGUEZ, P. (Coord.) (2016): Los Museos Pedagógicos en España. Entre la memoria y la creatividad. Gijón Sevilla: Trea, Universidad de Sevilla.

ÁlVAREZ DOMÍNGUEZ, P.; PAYÁ RICO, A. (2015): "Los Museos Pedagógicos en España: Tradición y futuro ante la difusión del Patrimonio Histórico Educativo”. En Rivera, R.; García Fernández, I. (Coords.). Museos y colecciones de la Universidad Complutense de Madrid. Madrid: Universidad Complutense de Madrid, pp. 237-242.

ASENSI DÍAZ J. (2015): "El museo de la educación de la Facultad de Formación del Profesorado de la Universidad Autónoma de Madrid”, en García Fernández, I. (ed): Congreso Internacional Museos Universitarios. Tradición y futuro. Libro de actas. Madrid: Universidad Complutense, pp. 381-388.

ÁVILA RUIZ, R.M. (2001): "El papel de la historia del arte en el curriculum". En Iber: Didáctica de las ciencias sociales, geografía e historia, pp. 67-80.

ÁVILA RUIZ, R.M. (2003): "Dificultades, obstáculos y necesidades formativas de la enseñanza y el aprendizaje del Patrimonio Histórico-Artístico”. En E. Ballesteros Arranz, C. Fernández Fernández, J. A. Molina Ruiz y P. Moreno Benito (coords.), El Patrimonio y 
la Didáctica de las Ciencias Sociales. Cuenca: Universidad de Castilla-la Mancha, pp. 163-177.

BAJO BAJO, M. J. (2018): "El uso de la obra de arte como instrumento en la formación inicial”. En C. López Torres, C.R. García Ruiz, y M. Sánchez Agustí (Eds.): Buscando formas de enseñar; investigar para innovar en didáctica de las Ciencias Sociales. Valladolid: Universidad de Valladolid, pp. 187-197.

CALAF, R. Y FONTAL, O. (2010): Como enseñar arte en la escuela, Madrid: Síntesis, [Enlace] (última consulta 27/07/2019).

CARREÑO RIVERO, M. (2007): “Museología y museografía de la educación”. En: Escolano Benito, A.. La cultura material de la escuela. En el Centenario de la Junta para Ampliación de Estudios, 1907-2007. Berlanga de Duero: CEINCE, pp. 91-110.

CARRIÓN GUTIEZ, A. (Coord.) (2015): Plan Nacional de Educación y Patrimonio. Madrid: Ministerio de Educación, Cultura y Deporte, [Enlace] (última consulta 12/07/2019).

CERROLAZA CALVO, S. (2018): "Los museos sin territorio. Una tipología de museo sin edificio”. En EME Experimental Illustration, Art \&Design, 6, pp. 80-89

COSSÍO, M.B., RUBIO, R., ALTAMIRA, R. (1890): Museo Pedagógico de Instrucción Primaria. Catálogo Provisional. Madrid: Imprenta de Fortanet.

CUENCA LÓPEZ, J.M., MARTÍN CÁCERES, M.J. (2014): Manual para el desarrollo de proyectos educativos en museos. Gijón: Trea.

DALMAU CARLES, J. (1953): Rudimentos de aritmética para las escuelas y colegios de primera enseñanza Libro del alumno Grado elemental. Barcelona: Dalmau Carles Pla.

DE LOS REYES LEOZ, J.L. (2009): “Del patrimonio cultural al museo infantil”. En Tarbiya, Revista de investigación e innovación educativa, 40. Madrid: Universidad Autónoma de Madrid, pp. 107-124.

DE LOS REYES LEOZ, J. L., MÉNDEZ ANDRÉS, R. (2016): “La función educativa de las ciencias sociales en la LOMCE. El ejemplo de la educación patrimonial en la enseñanza primaria”. En Revista Educación, Política y Sociedad, 1(2), 125-144.

DE QUESADA, E. (2013): El Turismo y el Arte. Iconografía de un siglo de Turismo en España. Madrid: Museo Casa de la Moneda, FNMT.

DE RINK, P. (2005): Cómo leer la pintura. Barcelona: Grupo Editorial Random House Mondadori.

DESVALLÉES, A. y MAIRESSE, F. (Dir.) (2010): Conceptos claves de museología. París: Armand Colin, ICOM.

EGEA VIVANCOS, A. y ARIAS FERRER, L. (2018): “Aprendizaje basado en objetos en Educación Secundaria: primeros resultados de una experiencia didáctica”. En C. López 
Torres, C.R. García Ruiz, y M. Sánchez Agustí (Eds.): Buscando formas de enseñar; investigar para innovar en didáctica de las Ciencias Sociales. Valladolid: Universidad de Valladolid, pp. 919-932.

ELMES, S. (2014): "The secrets of Andy Wharhol's time capsules". En [Enlace] (última consulta 12/07/2019) FONTAL MERILLAS, O. (2009): "Los museos de arte: un campo emergente de investigación e innovación para la enseñanza del arte”. En Revista electrónica interuniversitaria de formación del profesorado, vol. 12, 4, pp. 75-88.

FONTAL MERILLAS, O., MARÍN CEPEDA, S., GARCÍA CEBALLOS, S. (2015): Educación de las artes visuales y plásticas en Educación Primaria. Madrid: Paraninfo.

FONTAL MERILLAS, O., IBÁÑEZ-ETXEBERRIA, A., MARTÍNEZ RODRÍGUEZ, M., y RIVERO GRACIA, P. (2017): El patrimonio como contenido en la etapa de Primaria: del curriculum a la formación de maestros. En Revista Electrónica Interuniversitaria de Formación del Profesorado 20 (2), pp. 79-95.

GARCÍA ANDUJAR, N. (2015): "El Museo Jesús Asensi en el marco de los museos pedagógicos”. Revista de Didácticas Específicas, 13, pp. 173-185.

GARCÍA BLANCO, A. (1994): Didáctica del museo. El descubrimiento de los objetos. Madrid: De la Torre.

GARCÍA BLANCO, A. (1999): La exposición. Un medio de comunicación. Madrid: Akal.

GARCÍA DEL DUJO, Á. (1985): Museo Pedagógico Nacional. Teoría educativa y desarrollo histórico. Salamanca: Ediciones de la Universidad de Salamanca.

GÓMEZ TALAVERA, M. (2014): “Monetario del Infante don Gabriel de Borbón. Pieza del mes. Colecciones fundacionales. El Gabinete de antigüedades y monedas de la Real Biblioteca". Madrid, Museo Arqueológico Nacional, en [Enlace] (última consulta 6/07/2019).

GONZÁLEZ GALLEGO, I. (2002): "Las didácticas de área: un reciente campo científico”. En Revista de Educación, 328, pp. 11-34.

GONZÁLEZ MONFORT, N. (2011): "La presencia del patrimonio cultural en los currícula de educación infantil, primaria y secundaria obligatoria en España”. En Patrimonio Cultural, 5, 59-73.

GRAÑEDA MIÑON, P. (2014): "La moneda, algo más que dinero": el área temática de las colecciones numismáticas del Museo Arqueológico Nacional”. En Boletín del Museo Arqueológico Nacional, 32, pp. 553-570, en [Enlace] (última consulta 6/07/2019).

GRECO. A. (1962): Arte Vivo, Movimiento Dito. Alberto Greco. 24 de julio de 1962. [Enlace] (última consulta 30/07/2019). 
HERNÁNDEZ CARDONA, F.X. (2011): "Museografía didáctica”. En SANTACANA MESTRE, J. y SERRAT ANTOLÍ, N. (Coords.): Museografía didáctica. Barcelona: Planeta, pp. 23-61.

HERNÁNDEZ HERNÁNDEZ, F. (2002): “Aproximación a una tipología de museos”. En RdeM, 24-25, pp. 74-93.

HERRERO FABREGAT, C. (2012): "Hacia una didáctica integrada de las ciencias sociales”. En Didácticas Específicas, 6, pp. 140-158.

ICOM (2017): [Enlace] (última consulta 15/07/2019).

LEÓN. A. (2010): El museo: teoría, praxis y utopía. Madrid: Catedra.

MacGREGOR, N. (2012): La historia del mundo en 100 objetos. Barcelona: Penguin Random House Grupo Editorial.

MAILlO, A. (1954): Contar y medir la aritmética del párvulo. Burgos: Hijos de Santiago Rodríguez.

MALRAUX, A. (2017): El museo imaginario, Madrid: Cátedra.

MIRÓ ARGULLÓ, J. B., (2009): "Monedas de cartón en la Segunda República”, En Emblemata, 14, Zaragoza, pp. 465-468, en [Enlace] (última consulta 1/08/2019)

"ORDEN ECO/931/2002, de 17 de abril, por la que se acuerda la emisión, acuñación y puesta en circulación de monedas conmemorativas de la Presidencia Española de la Unión”. En BOE, 103. Madrid: Ministerio de Economía, 30/04/2002, p. 15739.

ORTEGA GALINDO, J. (1947): España primitiva a través de las monedas antiguas. Bilbao.

ORTEGA MORALES, N. (2002): La enseñanza-aprendizaje del arte: una innovación educativa de la Institución Libre de Enseñanza, Granada: Grupo Editorial Universitario.

OTERO MORÄN, P. (2016): "Un nuevo museo para una antigua colección. Monedas, medallas y "otras curiosidades" en el renovado Museo Arqueológico Nacional”. En Patrimonio numismático y museos: actas XV Congreso Nacional de Numismática, Madrid, 28-30 de octubre de 2014. Madrid: Museo Casa de la Moneda, pp. 27-60.

PALACIO ÁlVAREZ, A. (2008): "La experiencia de infantil en el arte español del siglo XX”. En Cabañas Bravo, M, López-Yarto Elizalde, A. y Rincón García, W.: Arte, poder y sociedad de los siglo XV al XX. Madrid: CSIC, pp. 661-672.

PAREDES LABRA, J. (2010): "Museo Pedagógico Virtual Vivo. Un proyecto de formación inicial de una universidad expandida hoy para una escuela expandida de mañana". En Tendencias pedagógicas, 16. Madrid: Universidad Autónoma de Madrid, en [Enlace].

PEARCE, S. M. (1994): Interpreting Objects and Collections. London, New York: Routledge. 
PÉREZ, C. (1999): 3 Propuestas para niños. Ángel Ferrant/Melendreras/Tono, 1930-35. Valencia:L'Eixam, pp. 7-9 y 27-28.

POULOT, D. (2011): Museo y museología. Madrid: Abada Editores.

Real Decreto 620/1987, de 10 de abril, por el que se aprueba el Reglamento de Museos de Titularidad Estatal y del Sistema Español de Museos, BOE núm. 114, de 13/05/1987.

REGUERA, I. (2010): “Aby Warburg, inventor del Museo Virtual”. En El País. [Enlace] (última consulta 15/07/2019).

RIVERA, R; GARCÍA FERNÁNDEZ, I (Coords.) (2015): Museos y colecciones de la Universidad Complutense de Madrid. Madrid: Universidad Complutense de Madrid

RIVIÈRE, G.H. (et al.) (1989): La muséologie selon Georges Henri Rivière. Paris: Dunod.

RODRÍGUEZ CHARENTÓN, A. (s/a): Lecciones de cálculo aritmética, geometria, dibujo y trabajo manual. Grado elemental. Madrid: Estudio de Juan Ortiz.

ROMERO SÁNCHEZ, G. (2017): "Los museos y las colecciones universitarias de patrimonio histórico educativo: concepto, diagnóstico y propuestas para impulsar su uso real”. En Cambil Hernández, M.de la E., Tudela Sánchez, A. (Coords.) (2017): Educación y Patrimonio Cultural. Fundamentos, contextos y estrategias ocultas. Madrid: Ediciones Pirámide, pp.239-257.

RUIZ BERRIO J. (2006): "Historia y museología de la educación. Despegue y reconversión de los museos pedagógicos”. En Historia de la Educación, 25, pp. 271-290.

RUIZ BERRIO, J. (2010): El patrimonio histórico-educativo. Su conservación y estudio. Madrid: Biblioteca Nueva.

S/A: La pintura por el recorte geométrico a base de rectas y curvas. Juan Ortiz Editor, s/f.

S/A: La pintura por el recorte geométrico a base de rectas. Juan Ortiz Editor, s/f.

SANTACANA MESTRE, J. (2011): "Museografía didáctica, museos y centros de interpretación del patrimonio histórico”. En Museografía didáctica, Barcelona: Planeta, pp. 63101.

SANTACANA I MESTRE, J., LLONCH MOLINA, N. (2012): Manual de didáctica del objeto en el museo. Gijón: Trea.

SANTACANA MESTRE, J. Y SERRAT ANTOLÍ, N. (Coords.), (2011): Museografía didáctica, Barcelona: Planeta.

SERRANO MORAL, C. (2018): "Qué ocurrió cuando vistamos el museo con las manos fuera de los bolsillos”, en C. López Torres, C.R. García Ruiz, y M. Sánchez Agustí (Eds.): Buscando formas de enseñar; investigar para innovar en didáctica de las Ciencias Sociales. Valladolid: Universidad de Valladolid, pp. 801-811. 
SOCIAS, I. (1996), "El valor del arte y la renovación de la didáctica de las Ciencias Sociales”. En Iber: Didáctica de las Ciencias Sociales, geografía e historia, 8, pp. 7-16.

VAZQUEZ RAMIL, M. R., (2018), El Patrimonio Histórico Educativo: una mirada desde las Ciencias Sociales. en C. López Torres, C.R. García Ruiz, y M. Sánchez Agustí (Eds.), Buscando formas de enseñar; investigar para innovar en didáctica de las Ciencias Sociales. Valladolid: Universidad de Valladolid, 663-675.

VERGARA, A. (2016): "Reflejos de arte y cultura en los cuadros de Clara Peeters", en Vergara, A. (Ed.): El arte de Clara Peeters. Madrid: Museo Nacional del Prado, pp. 1347.

VILLALBA SALVADOR, M. (2019) "Texto y contexto. El Museo Nacional de Artes Decorativas como fuente en la investigación histórico-educativa”. En Historia y Memoria de la Educación, 10, pp. 271-308.

VIÑAO FRAGO, A. (2012): "La historia material e inmaterial de la escuela: memoria, patrimonio y educación”. En Educação, vol. 35, 1, enero-abril. Porto Alegre, Brasil: Pontifícia Universidade Católica do Rio Grande do Sul, pp. 7-17.

WOODLIN, P., (1997): "El Museo de arte en el curriculum escolar". En Arte, individuo y sociedad, 9, pp. 79-90. 